\title{
Estimating the impact of physical distancing measures in containing COVID-19: an empirical analysis
}

Wee Chian $\mathrm{KOH}, \mathrm{PhD}^{*}$

Centre for Strategic and Policy Studies, Brunei Darussalam

The World Bank, Washington, DC

Lin NAING, MD

PAPRSB Institute of Health Sciences, Universiti Brunei Darussalam

Justin WONG, MPhil

Disease Control Division, Ministry of Health, Brunei Darussalam

* Corresponding author: Dr Wee Chian Koh

Centre for Strategic and Policy Studies, Simpang 347, Jalan Gadong, Bandar Seri Begawan BE1318, Brunei Darussalam

Email: wckoh@csps.org.bn

Phone: +6738177165

Word count: abstract 248 words; main text 3,240 words.

\section{Funding}

This research did not receive any specific grant from funding agencies in the public, commercial, or notfor-profit sectors.

\section{Ethical approval \\ Not required.}

\section{Conflict of interest}

All authors have no conflict of interest to declare.

\section{Acknowledgements}

We thank Dr Ying-Ru Lo, Head of Mission and WHO Representative to Malaysia, Brunei Darussalam and Singapore, for useful comments and suggestions.

\section{Authors' contributions}

WCK conceived and designed the study, collected the data, and conducted the statistical analyses. WCK and JW wrote the manuscript with critical feedback from LN. All authors contributed to and approved the final manuscript. 


\title{
Estimating the impact of physical distancing measures in containing COVID-19: an empirical analysis
}

\author{
Abstract \\ Background \\ Epidemic modelling studies predict that physical distancing is critical in containing COVID-19. However, \\ few empirical studies have validated this finding. Our study evaluates the effectiveness of different \\ physical distancing measures in controlling viral transmission.
}

\section{Methods}

We identified three distinct physical distancing measures with varying intensity and implemented at different times-international travel controls, restrictions on mass gatherings, and lockdown-type measures-based on the Oxford COVID-19 Government Response Tracker. We also estimated the timevarying reproduction number $\left(R_{t}\right)$ for 142 countries and tracked $R_{t}$ temporally for two weeks following the $100^{\text {th }}$ reported case in each country. We regressed $R_{t}$ on the physical distancing measures and other control variables (income, population density, age structure, and temperature) and performed several robustness checks to validate our findings.

\section{Findings}

Complete travel bans and all forms of lockdown-type measures have been effective in reducing average $\mathrm{R}_{\mathrm{t}}$ over the 14 days following the $100^{\text {th }}$ case. Recommended stay-at-home advisories and partial lockdowns are as effective as complete lockdowns in outbreak control. However, these measures have to be implemented early to be effective. Lockdown-type measures should be instituted two weeks before the 100th case and travel bans about a week before detection of the first case.

\section{Interpretation}

A combination of physical distancing measures, if implemented early, can be effective in containing COVID-19-tight border controls to limit importation of cases, encouraging physical distancing, moderately stringent measures such as working from home, and a full lockdown in the case of a probable uncontrolled outbreak.

\section{Funding}

None declared. 
medRxiv preprint doi: https://doi.org/10.1101/2020.06.11.20128074; this version posted June 12, 2020. The copyright holder for this preprint (which was not certified by peer review) is the author/funder, who has granted medRxiv a license to display the preprint in perpetuity.

\section{Research in context}

\section{Evidence before this study}

Evidence on the impact of physical distancing measures on containing COVID-19 has primarily relied on epidemic modelling studies. As cases accumulate worldwide, it has become possible to use empirical data to validate the model-based findings. The few empirical studies that analyze global case data find that lockdowns and international travel restrictions are important, but have not explored, beyond these broad findings, the intensity and timeliness of the various measures to inform policymaking.

\section{Added value of this study}

We assessed, at a normalized stage of the epidemic curve, how the intensity and implementation timing of various physical distancing measures in 142 countries affect viral transmission, measured by the timevarying reproduction number $\left(\mathrm{R}_{\mathrm{t}}\right)$. Other similar empirical studies treat the measures as binary variables, do not address the potential confounding effect of increased caseload on transmission, and do not use $\mathrm{R}_{\mathrm{t}}$ as the primary metric.

\section{Implications of all the available evidence}

Our results support the findings in modelling studies, and subsequent empirical studies, that physical distancing measures can limit disease spread. We found that full border control and complete lockdowns are effective, but less stringent measures such as stay-at-home recommendations and working from home are as effective. As such, the framing of lockdown measures as a binary approach may be counterproductive. Overall, these measures are only effective if they are implemented early. 
medRxiv preprint doi: https://doi.org/10.1101/2020.06.11.20128074; this version posted June 12, 2020. The copyright holder for this preprint (which was not certified by peer review) is the author/funder, who has granted medRxiv a license to display the preprint in perpetuity. It is made available under a CC-BY-NC-ND 4.0 International license .

\section{Introduction}

Coronavirus disease 2019 (COVID-19) is an emerging respiratory infectious disease caused by the severe acute respiratory syndrome coronavirus 2 (SARS-CoV-2), which was first detected in early December 2019 in Wuhan, China. As of May 31, 2020, it has affected 5.93 million people and resulted in more than 367,000 deaths globally (WHO 2020).

In the absence of effective therapeutics or vaccines, containment measures rely on the capacity to control viral transmission through non-pharmaceutical interventions (NPIs) (Kissler et al. 2020). Current evidence suggests that the effectiveness of case isolation and contact tracing strategies can be enhanced when combined with physical distancing measures in public settings (Chu et al. 2020; Kucharski et al. 2020). Governments worldwide have implemented various forms of physical distancing measure with varied stringency level and timeliness. The measures include school and workplace closures, cancellation of public events, restrictions on mass gatherings, public transport closures, stayat-home orders, restrictions on internal movements, and international travel controls. Due to the potential for socioeconomic disruptions caused by these measures, it is therefore important to quantify their impact on disease spread to inform policymaking, which has thus far relied primarily on epidemic modelling studies (Ferguson et al. 2020; Prem et al. 2020). As cases accumulate, it has become possible to use empirical data derived from real-world observations to validate the model-based estimates of the effectiveness of policy interventions.

In this paper, we assessed-at a normalized point on the epidemic curve-the impact of physical distancing measures on viral transmission measured by the time-varying reproduction number, $R_{t}$, which represents the expected number of secondary cases generated by a primary case at time t. A value of $R_{t}$ greater than one indicates that a sustained outbreak is likely. The goal of policy intervention is to bring $\mathrm{R}_{\mathrm{t}}$ below one, suggesting that the outbreak is under control.

\section{Methods}

\section{Physical distancing measures}

Data on physical distancing measures were obtained from the Oxford COVID-19 Government Response Tracker (OxCGRT), which collects information, starting from January 1, 2020, on a range of government policies, assigns a stringency score for the measures, and aggregates the data into a common index for 170 countries (May 28 version). We used the Stringency Index as an aggregate measure, which has a score between 0 and 100, with a higher index indicating increased stringency. We further examined the impact of specific measures: (i) school closures; (ii) workplace closures; (iii) cancellation of public events; (iv) restrictions on size of gatherings; (v) public transport closures; (vi) stay-at-home orders; (vii) restrictions on internal movements, and (viii) restrictions on international travel. These measures have an ordinal scale of severity or intensity. Further details on the OxCGRT database are provided in Hale et al. (2020).

\section{Estimation of the real-time reproduction number}


medRxiv preprint doi: https://doi.org/10.1101/2020.06.11.20128074; this version posted June 12, 2020. The copyright holder for this preprint (which was not certified by peer review) is the author/funder, who has granted medRxiv a license to display the preprint in perpetuity. It is made available under a CC-BY-NC-ND 4.0 International license .

We normalized the stage of disease spread to minimize the confounding effect of increased caseload on transmission: the impact of interventions is expected to be different at 10 and 1,000 cases. We used 100 total cases as the starting point for all countries to indicate an outbreak (Hartfield and Alizon 2013).

We estimated $R_{t}$ for 142 countries that have reported at least 100 cases as of May 28,2020 . The estimation covered the whole period from the first reported case to May 28 using a weekly sliding window based on the methods developed by Cori et al. (2013). We used data on new daily cases and the distribution of the generation time (time between infection of an index case and infection of a secondary case). We incorporated uncertainty in the generation time distribution with a mean of 3.6 days (sd: 0.7 days) and standard deviation of 3 days (sd: 0.8 days) and used a Gamma prior for the reproduction number with mean 2.6 and standard deviation 2 . These parameter estimates were obtained from the COVID-19 Epiforecasts project by the Centre for the Mathematical Modelling of Infectious Diseases at the London School of Hygiene and Tropical Medicine (see Abbott et al. 2020). Data on daily reported cases were obtained from the European Centre for Disease Prevention and Control and from the Johns Hopkins University Centre for Systems Science and Engineering COVID-19 Data Depository. $\mathrm{R}_{\mathrm{t}}$ was estimated using the EpiEstim package in $\mathrm{R}$ version 3.6.3 (R Foundation for Statistical Computing).

An important feature of examining $R_{t}$, instead of cumulative case numbers, is that, if the proportion of cases that are unreported remain constant throughout an outbreak, estimates of $R_{t}$ are unaffected by underreporting (Thompson et al. 2019).

\section{Regression model}

As countries have implemented and subsequently relaxed measures in response to the outbreak, establishing causality from such measures to a change in $R_{t}$ is challenging. To address possible reverse causality, we examined the measures that were in place at the time when 100 cases have been reported. We then tracked $R_{t}$ temporally over the next 14 days. The lagged measures thus controls for the endogenous response to viral transmission.

We regressed $R_{t}$ on physical distancing measures and other covariates. The control variables used were income level (log of GDP per capita at current US\$), population density (log of population per square kilometre), age structure (proportion of population aged 65 years and above), and air temperature (14day average after the $100^{\text {th }}$ case). These socioeconomic and environmental factors have been postulated to influence disease spread (Liu et al. 2020; Qiu et al. 2020). Data on GDP per capita, population density, and population above 65 years old were obtained from the World Bank's World Development Indicators, supplemented by the Central Intelligence Agency's The World Factbook. Data on temperature were collected from the Air Quality Open Data Platform and other online weather resources.

The empirical specification takes the following form:

$$
R_{i}=\alpha+\sum_{j=1}^{J} \beta_{1 j} X_{i j}+\sum_{k=1}^{K} \beta_{2 k} Z_{i k}+\varepsilon_{i}
$$

where $R_{i}=\sum_{t=1}^{14} R_{i, t}$ is the average reproduction number of country $i$ over the 14 days following the date of the $100^{\text {th }}$ case; $X_{i j}$ is country $i^{\prime}$ 's physical distancing measure of type $j$ on the date of the $100^{\text {th }}$ 
medRxiv preprint doi: https://doi.org/10.1101/2020.06.11.20128074; this version posted June 12, 2020. The copyright holder for this preprint (which was not certified by peer review) is the author/funder, who has granted medRxiv a license to display the preprint in perpetuity.

It is made available under a CC-BY-NC-ND 4.0 International license .

case; $Z_{i k}$ represents the country characteristic $k$ (income level, population density, age structure, and temperature) of country $i ; \alpha$ is a constant term, $\beta^{\prime}$ s are the regression coefficients, and $\varepsilon_{i}$ denotes the error term.

We also conducted ex-post predictions on the date of the $100^{\text {th }}$ case using equation (1) to make comparative assessments on how $\mathrm{R}_{\mathrm{t}}$ would be predicted to evolve relative to what has been observed in reality. All regression analyses were performed in Stata 14 (StataCorp LLC).

\section{Robustness checks}

We conducted a series of robustness checks to validate our results. We explored a shorter time horizon of seven days to address the possibility of new measures implemented after the $100^{\text {th }}$ case that could affect $R_{t}$. We also used the growth in total cases instead of $R_{t}$ as the dependent variable. To examine actual behavioural changes instead of de jure government policies, we used a de facto measure of physical distancing using mobility data from Google Community Mobility Reports.

\section{Results}

We first take a cursory look at the nature of the relationship between physical distancing measures and $\mathrm{R}_{\mathrm{t}}$, and then proceed to estimate the magnitudes using regression models.

Figure 1 shows how $R_{t}$ (average over the 14 days following the $100^{\text {th }}$ case) varies with the stringency of physical distancing measures (as of date of $100^{\text {th }}$ case). There are several important observations: (i) countries with more stringent measures tend to have lower $R_{t}$ on average, as illustrated by the downward sloping line; (ii) no country with a stringency index lower than 50 could bring average $R_{t}$ to below one within two weeks; and (iii) countries with $\mathrm{R}_{\mathrm{t}}$ less than 1.5 on the date of the $100^{\text {th }}$ case have generally kept total cases (size of the bubbles) at a manageable level (as of May 28). 
Figure 1. Stringency index of physical distancing measures on the date of the $100^{\text {th }}$ case and average reproduction numbers in the following two weeks

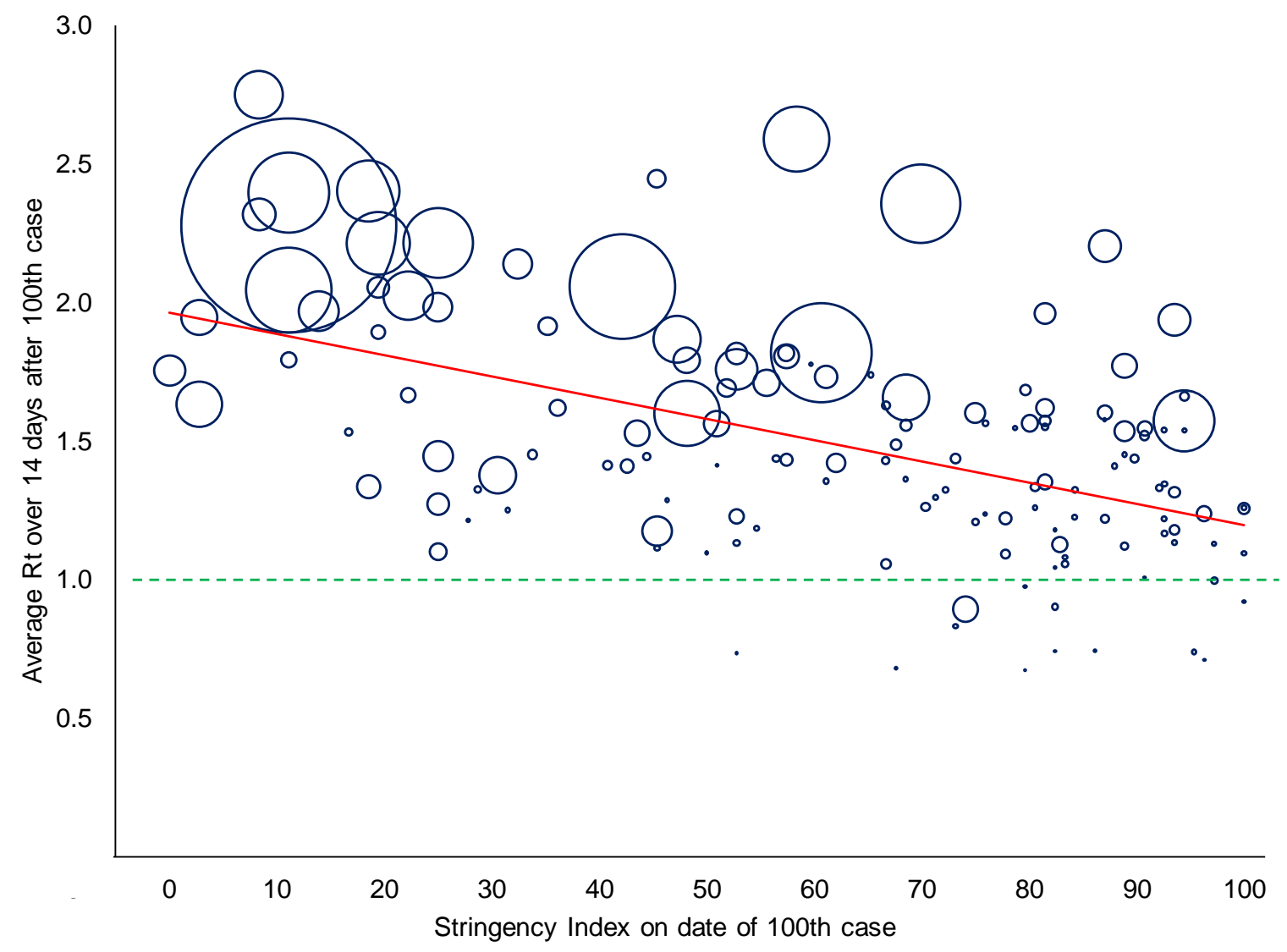

The time-varying reproduction number $R_{t}$ is the expected number of secondary cases generated by a primary case at time t. The Stringency Index is a composite index of physical distancing measures with a range of 0 to 100 , calculated by the Oxford COVID-19 Government Response Tracker (OxCGRT); a larger value indicates higher stringency. Each bubble represents a country, and the size of the bubble is proportional to the total number of reported cases as of May 28, 2020. The red solid line is the best linear fit of the relationship between the stringency level on the date of the $100^{\text {th }}$ reported case and the average $R_{t}$ in the following two weeks. The green dashed line is the $R_{t}$ threshold: a value below one indicates that a sustained outbreak is unlikely if the measures remain in place.

The average timing of implementation of the physical distancing measures is summarized in Table S1 in the Supplementary materials. The earliest policies to be implemented, on average, were restrictions on international travel, about 11 days before the detection of the first case. Cancellation of public events and school closures were the initial responses during the onset of an outbreak (about a week after the first case), followed by restrictions on the size of gatherings and more stringent measures such as workplace closures, restrictions on internal movement, stay-at-home orders, and public transport closures. On average, all these measures were implemented before the occurrence of the $100^{\text {th }}$ case.

Since several measures were implemented very close to one another, and due to the similar nature of some the measures, it is difficult to relate the observed changes in $\mathrm{R}_{\mathrm{t}}$ to a specific measure. We 
medRxiv preprint doi: https://doi.org/10.1101/2020.06.11.20128074; this version posted June 12, 2020. The copyright holder for this preprint (which was not certified by peer review) is the author/funder, who has granted medRxiv a license to display the preprint in perpetuity.

It is made available under a CC-BY-NC-ND 4.0 International license .

addressed this identification issue by grouping the measures, taking into account the implementation timing and correlation (Table S2 in Supplementary materials). We identified three distinct categories of physical distancing measures amenable to our analysis: (i) restrictions on international travel; (ii) restrictions on mass gatherings; and (iii) lockdown-type measures. Within each category, the intensity and timeliness of implementation varies (Table 1). In particular, we highlight the wide range of measures within a category. For instance, in lockdown-type measures, the least stringent being recommendations and government advisories on internal movement, up to complete lockdown with closure of all nonessential workplaces and stay-at-home requirements with minimal exceptions.

Restrictions on international travel are based on OxCGRT indicator C8. Restrictions on mass gatherings combine OxCGRT indicators C3 (cancel public events) and C4 (size restriction of gatherings). Lockdown combines OxCGRT indicators C2 (workplace closures), C6 (stay-at-home requirements), and C7 (restrictions on internal movement). A measure is considered to be implemented early if the number of days between implementation date and date of $100^{\text {th }}$ case is less than the global median, and late otherwise. For instance, Taiwan acted swiftly in banning arrivals for some regions ( 56 days before $100^{\text {th }}$ reported case, compared to global median of 31 days before $100^{\text {th }}$ case) while Sweden was late to implement border controls (12 days after $100^{\text {th }}$ case).

\section{Table 1. Physical distancing measures}

\begin{tabular}{|c|c|c|}
\hline Measure & Level & Definition \\
\hline \multirow{9}{*}{$\begin{array}{l}\text { Restrictions on } \\
\text { international } \\
\text { travel }\end{array}$} & $0-$ No measures & OxCGRT C8 $=0$ \\
\hline & 1 -Screening; late & OxCGRT C8 = 1; implemented late \\
\hline & 2 - Screening; early & OxCGRT C8 = 1; implemented early \\
\hline & 3 - Quarantine arrivals from high-risk regions; late & OxCGRT C8 = 2; implemented late \\
\hline & 4-Quarantine arrivals from high-risk regions; early & OxCGRT C8 = 2; implemented early \\
\hline & 5 - Ban on arrivals from some regions; late & OxCGRT C8 = 3; implemented late \\
\hline & 6 - Ban on arrivals from some regions; early & OxCGRT C8 = 3; implemented early \\
\hline & 7 - Ban on all regions or total border closure; late & OxCGRT C8 = 4; implemented late \\
\hline & $8-$ Ban on all regions or total border closure; early & OxCGRT C8 = 4; implemented early \\
\hline \multirow{7}{*}{$\begin{array}{l}\text { Restrictions on } \\
\text { mass gatherings }\end{array}$} & $0-$ No measures & OxCGRT C3 $=0$ and $\mathrm{C} 4=0$ \\
\hline & 1 - Recommend cancelling of public events; late & $\begin{array}{l}\text { OxCGRT C3 = } 1 \text { and C4 =0; } \\
\text { implemented late }\end{array}$ \\
\hline & 2-Recommend cancelling of public events; early & $\begin{array}{l}\text { OxCGRT C3 = } 1 \text { and C4 = 0; } \\
\text { implemented early }\end{array}$ \\
\hline & $\begin{array}{l}3-\text { Require cancelling of public events and } \\
\text { restrictions of gatherings above } 10 \text { people; late }\end{array}$ & $\begin{array}{l}\text { OxCGRT C } 3=2 \text { and C4 = 1,2 or } 3 \text {; } \\
\text { implemented late }\end{array}$ \\
\hline & $\begin{array}{l}4-\text { Require cancelling of public events and } \\
\text { restrictions of gatherings above } 10 \text { people; early }\end{array}$ & $\begin{array}{l}\text { OxCGRT C3 = } 2 \text { and C4 = 1,2 or } 3 \text {; } \\
\text { implemented early }\end{array}$ \\
\hline & $\begin{array}{l}5-\text { Require cancelling of public events and } \\
\text { restrictions on gatherings of } 10 \text { people or less; late }\end{array}$ & $\begin{array}{l}\text { OxCGRT C3 = } 2 \text { and C4 = 4; } \\
\text { implemented late }\end{array}$ \\
\hline & $\begin{array}{l}6-\text { Require cancelling of public events and } \\
\text { restrictions on gatherings of } 10 \text { people or less; } \\
\text { early }\end{array}$ & $\begin{array}{l}\text { OxCGRT C3 = } 2 \text { and C4 = 4; } \\
\text { implemented early }\end{array}$ \\
\hline \multirow{2}{*}{$\begin{array}{l}\text { Lockdown-type } \\
\text { measures }\end{array}$} & $0-$ No measures & OxCGRT C2 $=0$ and $C 6=0$ and $C 7=0$ \\
\hline & $\begin{array}{l}1 \text { - Recommend workplace closing (or work from } \\
\text { home), recommend not leaving house, or } \\
\text { recommend not to travel between regions/cities; }\end{array}$ & $\begin{array}{l}\text { OxCGRT } C 2 \leq 1 \text { and } C 6 \leq 1 \text { and } C 7 \leq 1 \text {; } \\
\text { implemented late }\end{array}$ \\
\hline
\end{tabular}


medRxiv preprint doi: https://doi.org/10.1101/2020.06.11.20128074; this version posted June 12, 2020. The copyright holder for this preprint (which was not certified by peer review) is the author/funder, who has granted medRxiv a license to display the preprint in perpetuity.

It is made available under a CC-BY-NC-ND 4.0 International license .

\author{
late \\ 2 - Recommend workplace closing (or work from \\ home), recommend not leaving house, or \\ OxCGRT C2 $\leq 1$ and $\mathrm{C} 6 \leq 1$ and $\mathrm{C} 7 \leq 1$; \\ recommend not to travel between regions/cities; \\ early \\ 3 - Require closing for some sectors or categories \\ of work or require not leaving house with \\ implemented early \\ exceptions for daily exercise, grocery shopping, \\ and essential trips; late \\ 4 - Require closing for some sectors or categories \\ of work or require not leaving house with \\ exceptions for daily exercise, grocery shopping, \\ and essential trips; early \\ 5 - Require closing of all but essential workplaces, \\ require not leaving house with minimal exceptions, \\ or restrictions on internal movement; late \\ 6 - Require closing of all but essential workplaces, \\ require not leaving house with minimal exceptions, \\ or restrictions on internal movement; early \\ OxCGRT C2 = 2 or C6 = 2; \\ implemented late \\ OxCGRT C2 = 2 or C6 = 2; \\ implemented early \\ OxCGRT C2 = 3 or C6 = 3 or $\mathrm{C7}=2$; \\ implemented late \\ OxCGRT C2 = 3 or $\mathrm{C} 6=3$ or $\mathrm{C} 7=2$; \\ implemented early \\ Authors' definitions using data from the Oxford COVID-19 Government Response Tracker (OxCGRT). A measure is \\ considered to be "early" if the number of days between implementation date and date of 100 " case is less than
} the median, and "late" otherwise.

Figures 2 to 4 show how $R_{t}$ varies with each physical distancing measure. In general, the more stringent the measure and the earlier its implementation, the lower the value of $R_{t}$. In the case of international travel restrictions, $R_{t}$ below one was only observed in countries that either implemented quarantine of arriving passengers from high-risk regions early, or enacted bans on arrivals. On mass gathering restrictions, $R_{t}$ less than one was observed in countries that either cancelled public events or limited the size of gatherings. Interestingly, one country (Brunei) managed to bring $R_{t}$ to below one without the need for any form of lockdown-type measures. Overall, countries with earlier and more stringent measures at the time of the $100^{\text {th }}$ case appeared to have recorded far fewer cases (as of May 28), although there are a few exceptions (e.g. Peru and Russia, despite early lockdowns). 
Figure 2. Restrictions on international travel on the date of the $100^{\text {th }}$ case and average reproduction numbers in the following two weeks

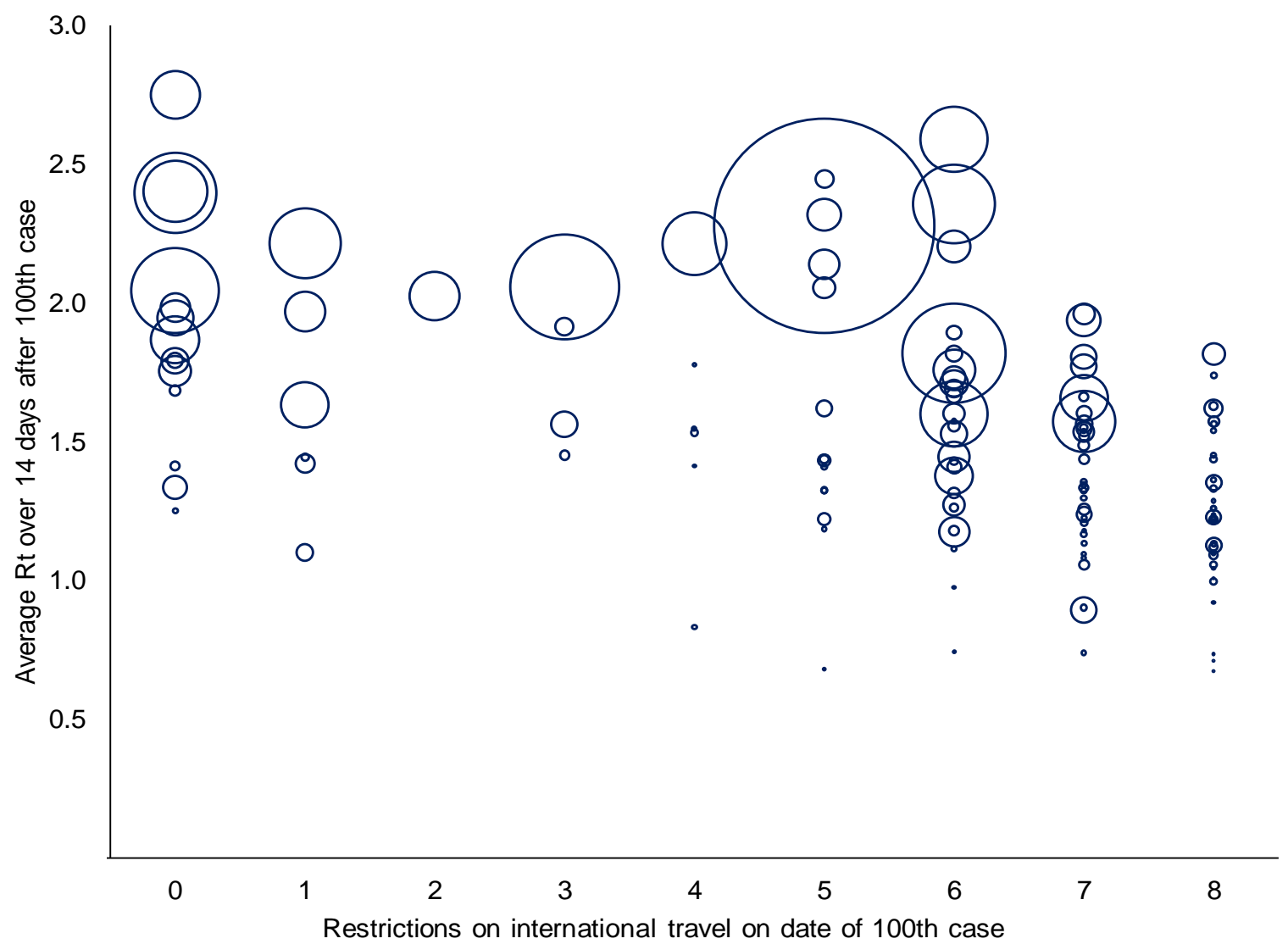

The time-varying reproduction number $R_{t}$ is the expected number of secondary cases generated by a primary case at time $t$. The specific measures on international travel restrictions are detailed in Table 1. Each bubble represents a country, and the size of the bubble is proportional to the total number of reported cases as of May 28, 2020. 
Figure 3. Restrictions on mass gatherings on the date of the $100^{\text {th }}$ case and average reproduction numbers in the following two weeks

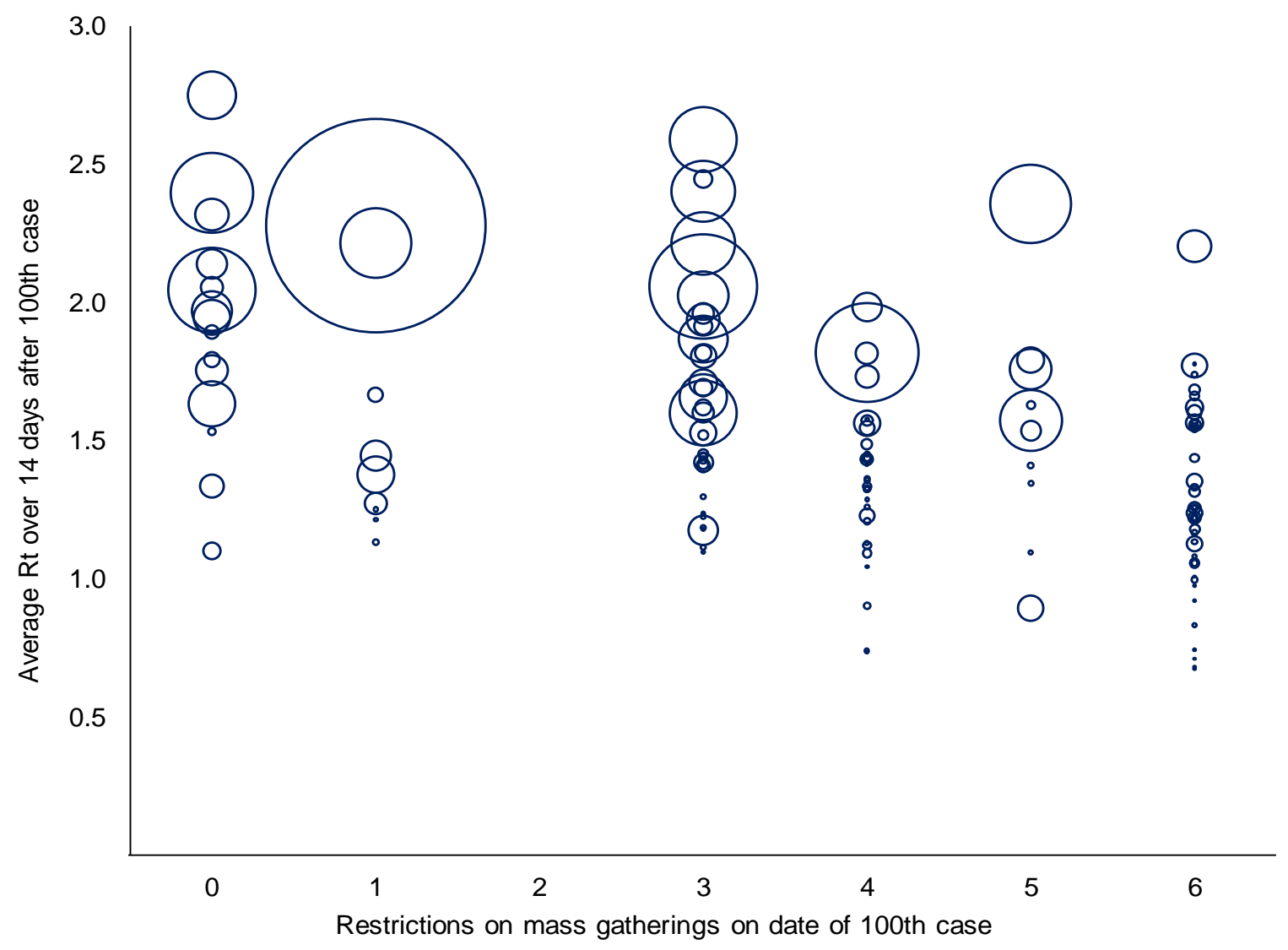

The time-varying reproduction number $R_{t}$ is the expected number of secondary cases generated by a primary case at time $t$. The specific measures on mass gathering restrictions are detailed in Table 1 . Each bubble represents a country, and the size of the bubble is proportional to the total number of reported cases as of May $28,2020$. 
Figure 4. Lockdown-type measures on the date of the $100^{\text {th }}$ case and average reproduction numbers in the following two weeks

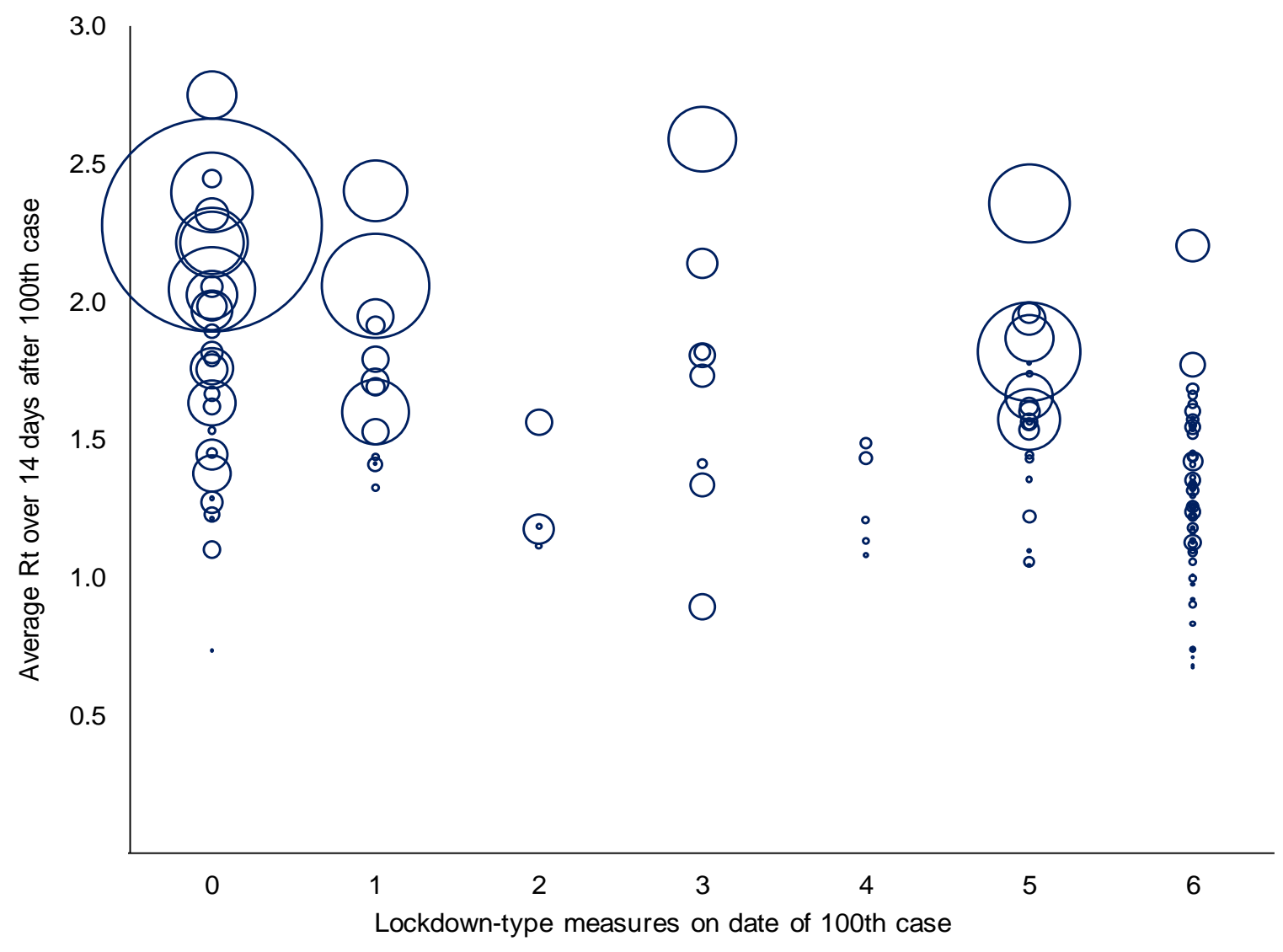

The time-varying reproduction number $R_{t}$ is the expected number of secondary cases generated by a primary case at time $t$. The specific measures on lockdown are detailed in Table 1. Each bubble represents a country, and the size of the bubble is proportional to the total number of reported cases as of May 28, 2020.

\section{Impact of physical distancing measures}

We first examine the impact of the Stringency Index on $R_{t}$. The results are reported in column (1) of Table 2. The estimated coefficient of the Stringency Index is negative and significant: an increase in the index by 10 points reduces $\mathrm{R}_{\mathrm{t}}$ by 0.06 ( $\left.95 \% \mathrm{Cl}:-0.08,-0.04\right)$. Among the other independent variables, warmer temperature is associated with a lower $\mathrm{R}_{\mathrm{t}}$ : an increase in the temperature of 10 degree Celsius reduces $\mathrm{R}_{\mathrm{t}}$ by 0.16 ( $\left.95 \% \mathrm{Cl}:-0.24,-0.09\right)$. 
medRxiv preprint doi: https://doi.org/10.1101/2020.06.11.20128074; this version posted June 12, 2020. The copyright holder for this preprint (which was not certified by peer review) is the author/funder, who has granted medRxiv a license to display the preprint in perpetuity.

It is made available under a CC-BY-NC-ND 4.0 International license .

Table 2. Estimated impact of the Stringency Index on COVID-19 transmission

\begin{tabular}{lcccc}
\hline \multicolumn{4}{c}{ Dependent variable } \\
\hline Stringency Index & $\mathrm{R}_{\mathrm{t}, 14}$ & $\mathrm{R}_{\mathrm{t}, 7}$ & $\mathrm{~g}$ & $\mathrm{R}_{\mathrm{t}, 14}$ \\
& $-0.0061^{* * *}$ & $-0.0072^{* * *}$ & $-0.1946^{* * *}$ & $(0.0454)$ \\
Google mobility & $(0.0012)$ & $(0.0017)$ & & $0.0052^{* * *}$ \\
& & & & $(0.0015)$ \\
In GDP per capita & & & -0.2865 & -0.0053 \\
& -0.0412 & -0.0427 & $(1.0912)$ & $(0.0325)$ \\
In population density & $(0.0285)$ & $(0.0399)$ & 0.1416 & -0.0148 \\
& -0.0126 & -0.0181 & $(0.8179)$ & $(0.0245)$ \\
\% age 65 in population & $(0.0213)$ & $(0.0299)$ & -0.0118 & 0.0034 \\
& 0.0006 & 0.0018 & $(0.2776)$ & $(0.0083)$ \\
Temperature & $(0.0072)$ & $(0.0101)$ & $-0.4665^{* * *}$ & $-0.0136^{* * *}$ \\
& $-0.0162^{* * *}$ & $-0.0184^{* * *}$ & $(0.1478)$ & $(0.0050)$ \\
Constant & $(0.0039)$ & $(0.0054)$ & $32.4252^{* * *}$ & $1.9881^{* * *}$ \\
& $2.5674^{* * *}$ & $2.8634 * * *$ & $(10.3474)$ & $(0.3084)$ \\
\hline Number of countries & $(0.2700)$ & $(0.3780)$ & 142 & 102 \\
$\mathrm{R}^{2}$ & 142 & 142 & 0.314 & 0.353 \\
Adjusted $\mathrm{R}^{2}$ & 0.388 & 0.314 & 0.289 & 0.320 \\
\hline
\end{tabular}

The dependent variable in columns (1) and (4), $R_{t, 14}$ is the average $R_{t}$ over the 14 days following the date of the $100^{\text {th }}$ case; $R_{t, 7}$ in column (2) is the average $R_{t}$ over the 7 days following the date of the $100^{\text {th }}$ case; $g$ in column (3) is the growth rate of total cases between the date of the $100^{\text {th }}$ case and the date 14 days later. The Stringency index is a composite index of physical distancing measures with a range of 0 to 100, calculated by the Oxford COVID-19 Government Response Tracker (OxCGRT). Mobility (from Google Community Mobility Reports) is the average percent change in visits to retail and recreation, grocery and pharmacy, parks, transit and workplaces on the date of the $100^{\text {th }}$ case compared to the median baseline value of the corresponding day of the week during January 3 to February 6,2020 , as a proxy measurement of de facto physical distancing; a positive coefficient indicates that a reduction in mobility reduces $R_{t, 14}$.

Standard errors are in parenthesis. ${ }^{* *},{ }^{* *}$, and ${ }^{*}$ represents statistical significance at the $1 \%, 5 \%$, and $10 \%$ level respectively.

We then assess the impact of the three categories of physical distancing measures individually, and then collectively. Table 3 reports the results. Columns (1) to (3) affirm the observations from Figures 2 to 4 that earlier and more stringent measures were associated with lower $\mathrm{R}_{\mathrm{t}}$. However, some of the significant results disappeared when all the variables were entered simultaneously.

Column (4) shows that travel bans on all regions and lockdown-type measures, if implemented early, significantly lowered $R_{t}$. Relative to no measures being taken, a total border closure reduces $R_{t}$ by 0.24 (95\% Cl: $-0.50,0.01)$; policies that recommend working from home or staying home reduce $\mathrm{R}_{\mathrm{t}}$ by 0.45 (95\% Cl: $-0.82,-0.07)$; a partial lockdown reduces $\mathrm{R}_{\mathrm{t}}$ by 0.38 (95\% $\left.\mathrm{Cl}:-0.72,-0.04\right)$; and a complete lockdown reduces $\mathrm{R}_{\mathrm{t}}$ by 0.32 ( $\left.95 \% \mathrm{Cl}:-0.55,-0.09\right)$. 
medRxiv preprint doi: https://doi.org/10.1101/2020.06.11.20128074; this version posted June 12, 2020. The copyright holder for this preprint (which was not certified by peer review) is the author/funder, who has granted medRxiv a license to display the preprint in perpetuity.

It is made available under a CC-BY-NC-ND 4.0 International license .

Table 3. Estimated impact of the type of physical distancing measures on COVID-19 transmission

\begin{tabular}{|c|c|c|c|c|}
\hline & (1) & (2) & (3) & (4) \\
\hline \multicolumn{5}{|c|}{ Restrictions on international travel } \\
\hline 1 & $\begin{array}{c}-0.1709 \\
(0.1688)\end{array}$ & & & $\begin{array}{c}-0.2678 \\
(0.1602)\end{array}$ \\
\hline 2 & $\begin{array}{c}-0.2877 \\
(0.3683)\end{array}$ & & & $\begin{array}{c}-0.3115 \\
(0.3604)\end{array}$ \\
\hline 3 & $\begin{array}{c}0.1086 \\
(0.2027)\end{array}$ & & & $\begin{array}{c}0.1362 \\
(0.2041)\end{array}$ \\
\hline 4 & $\begin{array}{c}-0.1742 \\
(0.1741)\end{array}$ & & & $\begin{array}{c}-0.1264 \\
(0.1682)\end{array}$ \\
\hline 5 & $\begin{array}{c}-0.1339 \\
(0.1337)\end{array}$ & & & $\begin{array}{c}-0.0530 \\
(0.1302)\end{array}$ \\
\hline 6 & $\begin{array}{c}-0.1433 \\
(0.1201)\end{array}$ & & & $\begin{array}{c}-0.0763 \\
(0.1214)\end{array}$ \\
\hline 7 & $\begin{array}{c}-0.3188^{* * *} \\
(0.1189)\end{array}$ & & & $\begin{array}{c}-0.1391 \\
(0.1256)\end{array}$ \\
\hline 8 & $\begin{array}{c}-0.4133^{* * *} \\
(0.1242)\end{array}$ & & & $\begin{array}{c}-0.2432 * \\
(0.1288)\end{array}$ \\
\hline \multicolumn{5}{|c|}{ Restrictions on mass gatherings } \\
\hline 1 & & $\begin{array}{c}-0.2361 \\
(0.1435)\end{array}$ & & $\begin{array}{c}-0.1620 \\
(0.1482)\end{array}$ \\
\hline 2 & & N/A & & N/A \\
\hline 3 & & $\begin{array}{c}-0.1495 \\
(0.1059)\end{array}$ & & $\begin{array}{c}-0.0308 \\
(0.1313)\end{array}$ \\
\hline 4 & & $\begin{array}{c}-0.4142^{* * *} \\
(0.1162)\end{array}$ & & $\begin{array}{c}-0.2064 \\
(0.1379)\end{array}$ \\
\hline 5 & & $\begin{array}{c}-0.2746^{* *} \\
(0.1366)\end{array}$ & & $\begin{array}{c}-0.1094 \\
(0.1595)\end{array}$ \\
\hline 6 & & $\begin{array}{c}-0.4791^{* * *} \\
(0.1073)\end{array}$ & & $\begin{array}{c}-0.2124 \\
(0.1471)\end{array}$ \\
\hline \multicolumn{5}{|c|}{ Lockdown-type measures } \\
\hline 1 & & & $\begin{array}{l}-0.0368 \\
(0.1094)\end{array}$ & $\begin{array}{c}-0.1366 \\
(0.1264)\end{array}$ \\
\hline 2 & & & $\begin{array}{l}-0.3318^{*} \\
(0.1747)\end{array}$ & $\begin{array}{c}-0.4465^{* *} \\
(0.1879)\end{array}$ \\
\hline 3 & & & $\begin{array}{l}-0.1107 \\
(0.1297)\end{array}$ & $\begin{array}{c}-0.1847 \\
(0.1391)\end{array}$ \\
\hline 4 & & & $\begin{array}{c}-0.5125^{* * *} \\
(0.1574)\end{array}$ & $\begin{array}{c}-0.3774^{* *} \\
(0.1714)\end{array}$ \\
\hline 5 & & & $\begin{array}{l}-0.1586 \\
(0.0954)\end{array}$ & $\begin{array}{c}-0.1083 \\
(0.1212)\end{array}$ \\
\hline
\end{tabular}


medRxiv preprint doi: https://doi.org/10.1101/2020.06.11.20128074; this version posted June 12, 2020. The copyright holder for this preprint (which was not certified by peer review) is the author/funder, who has granted medRxiv a license to display the preprint in perpetuity. It is made available under a CC-BY-NC-ND 4.0 International license .

\begin{tabular}{|c|c|c|c|c|}
\hline 6 & & & $\begin{array}{c}-0.4268 * * * \\
(0.0838)\end{array}$ & $\begin{array}{c}-0.3186 * * * \\
(0.1154)\end{array}$ \\
\hline In GDP per capita & $\begin{array}{c}-0.0207 \\
(0.0291)\end{array}$ & $\begin{array}{l}-0.0389 \\
(0.0294)\end{array}$ & $\begin{array}{l}-0.0505^{*} \\
(0.0290)\end{array}$ & $\begin{array}{c}-0.0642 * * \\
(0.0307)\end{array}$ \\
\hline In population density & $\begin{array}{l}-0.0191 \\
(0.0231)\end{array}$ & $\begin{array}{l}-0.0139 \\
(0.0221)\end{array}$ & $\begin{array}{l}-0.0059 \\
(0.0213)\end{array}$ & $\begin{array}{l}-0.0063 \\
(0.0226)\end{array}$ \\
\hline$\%$ age 65 in population & $\begin{array}{l}-0.0026 \\
(0.0077)\end{array}$ & $\begin{array}{c}0.0015 \\
(0.0073)\end{array}$ & $\begin{array}{c}0.0047 \\
(0.0072)\end{array}$ & $\begin{array}{c}0.0026 \\
(0.0073)\end{array}$ \\
\hline Temperature & $\begin{array}{c}-0.0181 * * * \\
(0.0044)\end{array}$ & $\begin{array}{c}-0.0171^{* * *} \\
(0.0039)\end{array}$ & $\begin{array}{c}-0.0157^{* * *} \\
(0.0038)\end{array}$ & $\begin{array}{c}-0.0152 * * * \\
(0.0041)\end{array}$ \\
\hline Constant & $\begin{array}{c}2.3303 * * * \\
(0.2766)\end{array}$ & $\begin{array}{c}2.4854^{* * *} \\
(0.2819)\end{array}$ & $\begin{array}{c}2.4326 * * * \\
(0.2687)\end{array}$ & $\begin{array}{c}2.7897 * * * \\
(0.3117)\end{array}$ \\
\hline Number of countries & 142 & 142 & 142 & 142 \\
\hline $\mathrm{R}^{2}$ & 0.372 & 0.402 & 0.435 & 0.512 \\
\hline Adjusted $\mathrm{R}^{2}$ & 0.313 & 0.361 & 0.392 & 0.417 \\
\hline
\end{tabular}

The dependent variable is the average $R_{t}$ over the 14 days since the date of the $100^{\text {th }}$ case. $R_{t}$, the timevarying reproduction number, is the expected number of secondary cases generated by a primary case at time $t$. The physical distancing measures are those that are in place on the date of the $100^{\text {th }}$ case; refer to Table 1 for the specific measures. Standard errors are in parenthesis. $* * *, * *$, and $*$ represents statistical significance at the $1 \%, 5 \%$, and $10 \%$ level respectively. N/A denotes not available.

To validate our results, we conducted several robustness checks. We tracked $R_{t}$ over seven days and used the growth of total cases instead of $\mathrm{R}_{\mathrm{t}}$ as the dependent variable. We also used a de facto measurement of physical distancing using Google mobility data-as opposed to de jure government announced measures - to examine the actual observed behaviour changes on $\mathrm{R}_{\mathrm{t}}$. The findings are largely unchanged, as reported in columns (2) to (4) in Table 2 and the Supplementary materials (Tables S3 and S4, Figure S1).

\section{Ex-post predictions}

We conducted ex-post predictions using the regression model in column (4) of Table 3 to retrospectively assess how $R_{t}$ would be predicted to evolve over the following two weeks, given the case history and physical distancing measures implemented on the date of the $100^{\text {th }}$ case, along with specific country characteristics. The predicted $\mathrm{R}_{\mathrm{t}}$ of the 142 countries are displayed in Table $\mathrm{S} 5$ in the Supplementary materials. Some countries had a lower $R_{t}$ over the two weeks following the $100^{\text {th }}$ case than predicted by the model, such as Japan, Brunei, Iceland, and Vietnam. By contrast, others, such as Turkey, Italy, and the United States had a higher $\mathrm{R}_{\mathrm{t}}$.

\section{Discussion}

We assessed, at a standardized stage of the outbreak at 100 cases, the impact of physical distancing measures on COVID-19 transmission, measured by $R_{t}$, and found that, on average, they have been effective in reducing $R_{t}$-if the measures were sufficiently stringent and implemented early. By using $R_{t}$ as the primary metric of transmission, instead of cumulative case counts in other similar studies (Castex 
medRxiv preprint doi: https://doi.org/10.1101/2020.06.11.20128074; this version posted June 12, 2020. The copyright holder for this preprint (which was not certified by peer review) is the author/funder, who has granted medRxiv a license to display the preprint in perpetuity. It is made available under a CC-BY-NC-ND 4.0 International license .

et al. 2020; Deb et al. 2020), we accounted for potential confounding effects caused by under-testing and underreporting of cases.

Our study provides empirical support to findings from modelling studies that highlight the role of physical distancing measures in containing COVID-19. We identified three distinct measures, implemented at different times-restrictions on international travel prior to the first reported case, restrictions on mass gatherings during the onset of an outbreak, and lockdowns at later stages.

Our analysis suggests a hierarchy of physical distancing measures that are effective in outbreak control. We found that lockdown-type measures had the largest effect on limiting viral transmission, followed by complete travel bans. These measures have to be implemented early to be effective-based on our definition of early implementation using the observed median timing across countries worldwide, lockdown measures should be instituted two weeks before the $100^{\text {th }}$ case and travel bans about a week before detection of the first case.

This accords with the findings in other studies that severe travel restrictions have been critical in slowing down infections in China (Kucharski et al. 2020) and around the world (Keita 2020), and also corroborates studies showing that lockdowns limited disease spread in Wuhan (Fang et al. 2020), Italy and Spain (Tobias 2020), and California (Friedson et al. 2020).

Importantly, our findings suggest that lockdowns measures should not be viewed in a binary approach. There is a wide range of lockdown-type measures from less stringent forms such as working from home up to complete movement restrictions, and all were shown to be effective in suppressing viral transmission. If implemented early, work from home and stay at home recommendations reduce Rt by 0.45 (95\% Cl: $-0.82,-0.07)$; a partial lockdown reduces $\mathrm{R}_{\mathrm{t}}$ by 0.38 ( $\left.95 \% \mathrm{Cl}:-0.72,-0.04\right)$; and a complete lockdown reduces $\mathrm{R}_{\mathrm{t}}$ by 0.32 ( $\left.95 \% \mathrm{Cl}:-0.55,-0.09\right)$. Across these three grades of lockdown-type measures, the $95 \% \mathrm{Cl}$ of their effect sizes overlap suggesting no significant difference in effectiveness across these measures. This finding is replicated even when assessed against other indicators of outbreak control, such as the increase in cumulative cases. As such, we suggest that early on in the outbreak, complete lockdowns may be unnecessary to control viral transmission, given the availability of other equally effective and more sustainable approaches. This is particularly important for the poorest countries. More than four-fifths of low- and lower-middle income countries have imposed complete lockdowns at the time of 100 reported cases (compared to three-fifths in upper-middle income and less than one-third in high-income countries), with potentially severe socioeconomic consequences, having already been hit by the slump in global economic activity, including sharp declines in remittances, tourism receipts, and commodity revenues (World Bank 2020).

Measures that recommend workplace closures or staying at home have been effective, implying that voluntary physical distancing has played an important role. In the United States, the decrease in mobility has been found to be largely voluntary, reflecting greater awareness of risk (Maloney and Taskin 2020). Japan has achieved success without the need for a complete lockdown. Clear public health messaging and voluntary practice of physical distancing shaped by cultural norms such as mask wearing, avoiding handshakes, and keeping silence when taking public transport and during events such as funerals, have been critical in limiting disease spread (Sposato 2020).

Overall, our analysis suggests that a combination of physical distancing measures may yield the most beneficial outcomes: international travel restrictions to limit imported cases from high-risk regions, 
medRxiv preprint doi: https://doi.org/10.1101/2020.06.11.20128074; this version posted June 12, 2020. The copyright holder for this preprint (which was not certified by peer review) is the author/funder, who has granted medRxiv a license to display the preprint in perpetuity. It is made available under a CC-BY-NC-ND 4.0 International license .

encouraging voluntary social distancing, moderate forms of lockdown-type measures such as working from home and only leaving the house for necessary activities, and complete lockdowns in areas or provinces with more severe outbreaks. The implementation timeliness of these measures invariably depends on the country-specific context, including public acceptance and institutional capacity.

Countries that have been relatively successful share these common elements. Despite an international travel hub and its close proximity to Wuhan, early border control and the practice of personal protective behaviours, including the use of face masks, contributed to Hong Kong's success in controlling viral transmission (Wong et al. 2020). Taiwan and Brunei responded quickly by instituting border control and reassured the public by delivering timely information on the epidemic (Wang et al. 2020; Wong et al. 2020). Targeted lockdown-type measures in Vietnam, coupled with mask wearing and consistent public health messaging, helped to contain disease spread (Duc Huynh 2020).

Our study has several limitations. First, although we controlled for several country characteristics, our model could suffer from omitted variable bias as behavioural variables, such as mask wearing, were unaccounted for due to lack of data. Second, beyond physical distancing measures, other NPIs such as early case isolation and aggressive contact tracing and quarantine are critical elements of a successful containment strategy (Ferguson et al. 2020), which we could not control for, again due to the lack of data. Third, although a significant amount of effort has been put into the construction of the OxCGRT database with a global coverage and a systematic classification of government policies, there could be some reporting errors or data quality issues. Moreover, our country-level analysis may miss the variation of policies implemented at the city/county/province level. Nonetheless, the database is the most comprehensive to date.

\section{Conclusion}

Physical distancing measures have been applied in arguably every country that is fighting COVID-19. Although modelling studies have shown the importance of physical distancing in stemming disease spread, few empirical studies have validated this finding. We provide empirical support and quantified the impact of physical distancing measures in lowering the reproduction number, particularly lockdowntype measures and border closures. Moreover, we found that less stringent lockdown-type measures, such as encouraging working from home and staying home unless necessary were as effective as complete lockdowns in reducing transmission. However, all these measures have to be implemented early to be effective. As many countries are in the midst of de-escalating, we suggest that some combination of these measures-empirically justified-should be considered in containing subsequent waves of COVID-19.

\section{References}

Abbott S, Hellewell J, Thompson RN, Sherratt K, Gibbs HP, Bosse NI, et al. Estimating the time-varying reproduction number of SARS-CoV-2 using national and subnational case counts. Wellcome Open Research 2020; 5: 112.

Castex G Dechter E, Lorca M. COVID-19: cross-country heterogeneity in effectiveness of nonpharmaceutical interventions. CEPR Covid Economics 2020; 14: 175-199. 
medRxiv preprint doi: https://doi.org/10.1101/2020.06.11.20128074; this version posted June 12, 2020. The copyright holder for this preprint (which was not certified by peer review) is the author/funder, who has granted medRxiv a license to display the preprint in perpetuity. It is made available under a CC-BY-NC-ND 4.0 International license .

Chu DK, AkI EA, Duda S, Solo K, Yaacoub S, Schünemann HJ, et al. Physical distancing, face masks, and eye protection to prevent person-to-person transmission of SARS-CoV-2 and COVID-19: a systematic review and meta analysis. The Lancet. 2020.

Cori A, Ferguson NM, Fraser C, Cauchemez S. A new framework and software to estimate time-varying reproduction numbers during epidemics. American Journal of Epidemiology 2013; 178(9): 1505-1512.

Deb P, Furceri D, Ostry JD, Tawk N. The effect of containment measures on the COVID-19 pandemic. CEPR Covid Economics 2020; 19: 53-86.

Duc Huynh TL. The COVID-19 containment in Vietnam: what are we doing? Journal of Global Health 2020; 10: 010338.

Fang H, Wang L, Yang Y. Human mobility restrictions and the spread of the novel coronavirus (2019$\mathrm{nCoV}$ ) in China. NBER Working Paper 26906. Cambridge MA: National Bureau of Economic Research. 2020.

Ferguson N, Laydon D, Nedjati-Gilani G, Imai N, Ainslie K, Baguelin M, et al. Report 9 - Impact of nonpharmaceutical interventions (NPIs) to reduce COVID-19 mortality and healthcare demand. Imperial College London. 2020.

Friedson IF, McNichols D, Sabia JJ, Dave D. Did California's Shelter-in-place order work? Early coronavirus-related public health effects. NBER Working Paper 26992. Cambridge MA: National Bureau of Economic Research. 2020.

Hale T, Angrist N, Kira B, Petherick A, Phillips T, Webster S. Variation in government responses to COVID19. Blavatnik School of Government Working Paper 2020/032. University of Oxford. 2020.

Hartfield M, Alizon S. Introducing the outbreak threshold in epidemiology. PLoS Pathogen 2013; 9(6): e1003277.

Keita S. Air passenger mobility, travel restrictions, and the transmission of the covid-19 pandemic between countries. CEPR Covid Economics 2020; 9: 77-96.

Kissler SM, Tedijanto C, Goldstein E, Grad YH, Lipsitch M. Projecting the transmission dynamics of SARSCoV-2 through the postpandemic period. Science. 2020.

Kucharski AJ, Russell TW, Diamond C, Liu Y, Edmunds J, Funk S, Eggo RM, et al. Early dynamics of transmission and control of COVID-19: a mathematical modelling study. The Lancet Infectious Diseases 2020; 20(5): P553-558.

Liu J, Zhou J, Yao J, Zhang X, Li L, Xu X, et al. Impact of meteorological factors on the COVID-19 transmission: a multi-city study in China. Science of The Total Environment 2020; 726: 138513.

Maloney W, Taskin T. Determinants of social distancing and economic activity during COVID-19: a global view. CEPR Covid Economics 2020; 13: 157-177.

Prem K, Liu Y, Russell TW, Kucharski AJ, Eggo RM, Davies N, et al. The effect of control strategies to reduce social mixing on outcomes of the COVID-19 epidemic in Wuhan, China: a modelling study. The Lancet Public Health 2020; 5(5): E261-E270. 
medRxiv preprint doi: https://doi.org/10.1101/2020.06.11.20128074; this version posted June 12, 2020. The copyright holder for this preprint (which was not certified by peer review) is the author/funder, who has granted medRxiv a license to display the preprint in perpetuity.

It is made available under a CC-BY-NC-ND 4.0 International license.

Qiu Y, Chen X, Shi W. Impacts of social and economic factors on the transmission of coronavirus disease 2019 (COVID-19) in China. Journal of Population Economics. 2020.

Sposato W. Japan's halfhearted coronavirus measures are working anyway. Foreign Policy. May 14, 2020. https://foreignpolicy.com/2020/05/14/japan-coronavirus-pandemic-lockdown-testing/

Thompson RN, Stockwin JE, van Gaalen RD, Polonsky JA, Kamvar ZN, Demarsh PA, et al. Improved inference of time-varying reproduction numbers during infectious disease outbreaks. Epidemics 2019; 29: 100356.

Tobias A. Evaluation of the lockdowns for the SARS-CoV-2 epidemic in Italy and Spain after one month follow up. Science of The Total Environment 2020; 725: 138539.

Wang CJ, Ng CY, Brook RH. Response to COVID-19 in Taiwan: big data analytics, new technology, and proactive testing. JAMA 2020; 323(14): 1341-1342.

WHO. Coronavirus disease (COVID-19) Situation Report - 132. Geneva: World Health Organization. 2020.

Wong J, Koh WC, Alikhan MF, Abdul Aziz ABZ, Naing L. Responding to COVID-19 in Brunei Darussalam: lessons for small countries. Journal of Global Health. 2020.

Wong SYS, Kwok KO, Chan FKL. What can countries learn from Hong Kong's response to the COVID-19 pandemic? CMAJ 2020; 192(19): E511-E515.

World Bank. Global Economic Prospects, June 2020. Washington, DC: World Bank. 2020. 
medRxiv preprint doi: https://doi.org/10.1101/2020.06.11.20128074; this version posted June 12, 2020. The copyright holder for this preprint (which was not certified by peer review) is the author/funder, who has granted medRxiv a license to display the preprint in perpetuity.

\section{Supplementary materials}

Table S1. Physical distancing measures

\begin{tabular}{lcccc}
\hline Physical distancing measure & $\begin{array}{c}\text { No. of countries } \\
\text { with measures }\end{array}$ & $\begin{array}{c}\text { Average date of } \\
\text { implementation }\end{array}$ & $\begin{array}{c}\text { Average days } \\
\text { after 1 }\end{array}$ case & $\begin{array}{c}\text { Average days } \\
\text { after } \mathbf{1 0 0}^{\text {th }} \text { case }\end{array}$ \\
\hline Restrictions on international travel & 167 & February 22, 2020 & -10.8 & -33.4 \\
Cancel public events & 165 & March 11, 2020 & 8.3 & -14.6 \\
School closures & 167 & March 12, 2020 & 9.3 & -13.5 \\
Restrictions on size of gatherings & 157 & March 17, 2020 & 13.8 & -9.1 \\
Workplace closures & 155 & March 17, 2020 & 14.9 & -7.6 \\
Restrictions on internal movement & 155 & March 19, 2020 & 16.6 & -6.2 \\
Stay-at-home orders & 152 & March 22, 2020 & 18.5 & -5.0 \\
Public transport closures & 130 & March 22, 2020 & 18.5 & -4.0 \\
\hline
\end{tabular}

Author's calculations based on the Oxford COVID-19 Government Response Tracker (OxCGRT). Data of 170 countries as of May 28, 2020.

Table S2. Pairwise correlation of physical distancing measures

\begin{tabular}{lcccccccc}
\hline & I & II & III & IV & V & VI & VII & VIII \\
\hline I. School closure & 1 & & & & & & & \\
II. Workplace closure & 0.552 & 1 & & & & & & \\
III. Cancel public events & 0.711 & 0.474 & 1 & & & & & \\
IV. Size restriction on gathering & 0.534 & 0.489 & 0.617 & 1 & & & & \\
V. Public transport closure & 0.404 & 0.534 & 0.408 & 0.450 & 1 & & & \\
VI. Stay-at-home order & 0.445 & 0.635 & 0.437 & 0.548 & 0.604 & 1 & & \\
VII. Internal movement restriction & 0.502 & 0.575 & 0.533 & 0.592 & 0.631 & 0.689 & 1 & \\
VIII. International travel restriction & 0.475 & 0.342 & 0.502 & 0.464 & 0.450 & 0.432 & 0.512 & 1 \\
\hline
\end{tabular}

Author's calculations based on the Oxford COVID-19 Government Response Tracker (OxCGRT). Data of 170 countries as of May 28, 2020. 
medRxiv preprint doi: https://doi.org/10.1101/2020.06.11.20128074; this version posted June 12, 2020. The copyright holder for this preprint (which was not certified by peer review) is the author/funder, who has granted medRxiv a license to display the preprint in perpetuity.

It is made available under a CC-BY-NC-ND 4.0 International license .

Table S3. Estimated impact of the type of physical distancing measures on COVID-19 transmission

\begin{tabular}{|c|c|c|c|c|}
\hline & (1) & (2) & (3) & (4) \\
\hline \multicolumn{5}{|c|}{ Restrictions on international travel } \\
\hline 1 & $\begin{array}{l}-0.2287 \\
(0.2299)\end{array}$ & & & $\begin{array}{l}-0.3312 \\
(0.2209)\end{array}$ \\
\hline 2 & $\begin{array}{c}-0.4322 \\
(0.5014)\end{array}$ & & & $\begin{array}{c}-0.5259 \\
(0.4968)\end{array}$ \\
\hline 3 & $\begin{array}{c}0.3088 \\
(0.2759)\end{array}$ & & & $\begin{array}{c}0.3184 \\
(0.2813)\end{array}$ \\
\hline 4 & $\begin{array}{c}-0.3192 \\
(0.2371)\end{array}$ & & & $\begin{array}{l}-0.2829 \\
(0.2319)\end{array}$ \\
\hline 5 & $\begin{array}{r}-0.1270 \\
(0.182)\end{array}$ & & & $\begin{array}{l}-0.0403 \\
(0.1795)\end{array}$ \\
\hline 6 & $\begin{array}{c}-0.2306 \\
(0.1636)\end{array}$ & & & $\begin{array}{c}-0.1872 \\
(0.1674)\end{array}$ \\
\hline 7 & $\begin{array}{c}-0.4069 * * \\
(0.1618)\end{array}$ & & & $\begin{array}{l}-0.2500 \\
(0.1731)\end{array}$ \\
\hline 8 & $\begin{array}{c}-0.5393^{* * *} \\
(0.1691)\end{array}$ & & & $\begin{array}{c}-0.3815^{* *} \\
(0.1775)\end{array}$ \\
\hline \multicolumn{5}{|c|}{ Restrictions on mass gatherings } \\
\hline 1 & & $\begin{array}{c}-0.1673 \\
(0.2002)\end{array}$ & & $\begin{array}{l}-0.0474 \\
(0.2043)\end{array}$ \\
\hline 2 & & N/A & & N/A \\
\hline 3 & & $\begin{array}{c}-0.0738 \\
(0.1477)\end{array}$ & & $\begin{array}{c}0.1158 \\
(0.1810)\end{array}$ \\
\hline 4 & & $\begin{array}{c}-0.3960^{* *} \\
(0.1621)\end{array}$ & & $\begin{array}{l}-0.0997 \\
(0.1902)\end{array}$ \\
\hline 5 & & $\begin{array}{c}-0.1712 \\
(0.1906)\end{array}$ & & $\begin{array}{c}0.0713 \\
(0.2198)\end{array}$ \\
\hline 6 & & $\begin{array}{c}-0.5214^{* * *} \\
(0.1497)\end{array}$ & & $\begin{array}{l}-0.1476 \\
(0.2027)\end{array}$ \\
\hline \multicolumn{5}{|c|}{ Lockdown } \\
\hline 1 & & & $\begin{array}{l}0.0769 \\
0.1522)\end{array}$ & $\begin{array}{l}-0.1082 \\
(0.1742)\end{array}$ \\
\hline 2 & & & $\begin{array}{c}-0.5917^{* *} \\
(0.2432)\end{array}$ & $\begin{array}{c}-0.8266^{* * *} \\
(0.2590)\end{array}$ \\
\hline 3 & & & $\begin{array}{l}-0.1475 \\
(0.1805)\end{array}$ & $\begin{array}{l}-0.2515 \\
(0.1918)\end{array}$ \\
\hline 4 & & & $\begin{array}{c}-0.5442^{* *} \\
(0.2190)\end{array}$ & $\begin{array}{l}-0.4082^{*} \\
(0.2363)\end{array}$ \\
\hline 5 & & & $\begin{array}{l}-0.1845 \\
(0.1328)\end{array}$ & $\begin{array}{l}-0.1395 \\
(0.1671)\end{array}$ \\
\hline
\end{tabular}


medRxiv preprint doi: https://doi.org/10.1101/2020.06.11.20128074; this version posted June 12, 2020. The copyright holder for this preprint (which was not certified by peer review) is the author/funder, who has granted medRxiv a license to display the preprint in perpetuity. It is made available under a CC-BY-NC-ND 4.0 International license .

\begin{tabular}{lcccc}
\hline 6 & & $-0.4961^{* * *}$ & $-0.3690^{* *}$ \\
In GDP per capita & & $(0.1166)$ & $(0.1591)$ \\
& -0.0231 & -0.0411 & -0.0477 & -0.0647 \\
In population density & $(0.0396)$ & $(0.041)$ & $(0.0404)$ & $(0.0424)$ \\
& -0.0225 & -0.0207 & -0.0091 & -0.0089 \\
\% age 65 in population & $(0.0315)$ & $(0.0308)$ & $(0.0296)$ & $(0.0311)$ \\
& -0.0028 & 0.0033 & 0.0062 & 0.0030 \\
Temperature & $(0.0105)$ & $(0.0102)$ & $(0.0100)$ & $(0.0101)$ \\
& $-0.0210^{* * *}$ & $-0.0197^{* * *}$ & $-0.0173^{* * *}$ & $-0.0170^{* * *}$ \\
Constant & $(0.0059)$ & $(0.0054)$ & $(0.0053)$ & $(0.0057)$ \\
& $2.6568^{* * *}$ & $2.7066^{* * *}$ & $2.6327^{* * *}$ & $3.0237^{* * *}$ \\
\hline Number of countries & $(0.3766)$ & $(0.3933)$ & $(0.3739)$ & $(0.4297)$ \\
$\mathrm{R}^{2}$ & 142 & 142 & 142 & 142 \\
Adjusted $\mathrm{R}^{2}$ & 0.334 & 0.334 & 0.375 & 0.470 \\
\hline
\end{tabular}

The dependent variable is the average $R_{t}$ over the 7 days since the date of the $100^{\text {th }}$ case. $R_{t}$, the time-varying reproduction number, is the expected number of secondary cases generated by a primary case at time $t$. The physical distancing measures are those that are in place on the date of the $100^{\text {th }}$ case; refer to Table 1 for the specific measures. Standard errors are in parenthesis. ${ }^{* * *}, * *$, and $*$ represents statistical significance at the $1 \%, 5 \%$, and $10 \%$ level respectively. N/A denotes not available. 
medRxiv preprint doi: https://doi.org/10.1101/2020.06.11.20128074; this version posted June 12, 2020. The copyright holder for this preprint (which was not certified by peer review) is the author/funder, who has granted medRxiv a license to display the preprint in perpetuity.

It is made available under a CC-BY-NC-ND 4.0 International license .

Table S4. Estimated impact of the type of physical distancing measures on growth of COVID-19 cases

\begin{tabular}{|c|c|c|c|c|}
\hline & (1) & (2) & (3) & (4) \\
\hline \multicolumn{5}{|c|}{ Restrictions on international travel } \\
\hline 1 & $\begin{array}{c}-11.5241^{*} \\
(6.4055)\end{array}$ & & & $\begin{array}{c}-13.9037 * * \\
(6.3857)\end{array}$ \\
\hline 2 & $\begin{array}{c}-4.3420 \\
(13.9714)\end{array}$ & & & $\begin{array}{c}-6.8805 \\
(14.3637)\end{array}$ \\
\hline 3 & $\begin{array}{l}-3.1768 \\
(7.6889)\end{array}$ & & & $\begin{array}{l}-1.5921 \\
(8.1343)\end{array}$ \\
\hline 4 & $\begin{array}{c}-11.5567^{*} \\
(6.6056)\end{array}$ & & & $\begin{array}{l}-9.7012 \\
(6.7039)\end{array}$ \\
\hline 5 & $\begin{array}{l}-6.7669 \\
(5.0718)\end{array}$ & & & $\begin{array}{l}-4.3670 \\
(5.1914)\end{array}$ \\
\hline 6 & $\begin{array}{l}-8.9413^{*} \\
(4.5579)\end{array}$ & & & $\begin{array}{l}-6.2495 \\
(4.8393)\end{array}$ \\
\hline 7 & $\begin{array}{c}-14.9550 * * \\
(4.5095)\end{array}$ & & & $\begin{array}{l}-9.4285^{*} \\
(5.0047)\end{array}$ \\
\hline 8 & $\begin{array}{c}-15.3598^{* *} \\
(4.7113)\end{array}$ & & & $\begin{array}{l}-9.8495^{*} \\
(5.1321)\end{array}$ \\
\hline \multicolumn{5}{|c|}{ Restrictions on mass gatherings } \\
\hline 1 & & $\begin{array}{c}-11.3489 * * \\
(5.5239)\end{array}$ & & $\begin{array}{l}-8.0236 \\
(5.9083)\end{array}$ \\
\hline 2 & & N/A & & N/A \\
\hline 3 & & $\begin{array}{l}-6.4666 \\
(4.0747)\end{array}$ & & $\begin{array}{l}-0.1768 \\
(5.2319)\end{array}$ \\
\hline 4 & & $\begin{array}{c}-14.0559 * * * \\
(4.4727)\end{array}$ & & $\begin{array}{l}-6.2775 \\
(5.4983)\end{array}$ \\
\hline 5 & & $\begin{array}{c}-10.5430 * * \\
(5.2583)\end{array}$ & & $\begin{array}{l}-2.8170 \\
(6.3564)\end{array}$ \\
\hline 6 & & $\begin{array}{c}-15.9865^{* * *} \\
(4.1313)\end{array}$ & & $\begin{array}{l}-5.9179 \\
(5.8615)\end{array}$ \\
\hline \multicolumn{5}{|c|}{ Lockdown } \\
\hline 1 & & & $\begin{array}{l}-3.0011 \\
(4.2961)\end{array}$ & $\begin{array}{l}-6.9561 \\
(5.0370)\end{array}$ \\
\hline 2 & & & $\begin{array}{l}-10.9708 \\
(6.8614)\end{array}$ & $\begin{array}{c}-14.9819 * * \\
(7.4892)\end{array}$ \\
\hline 3 & & & $\begin{array}{c}0.2952 \\
(5.0943)\end{array}$ & $\begin{array}{l}-2.7972 \\
(5.5463)\end{array}$ \\
\hline 4 & & & $\begin{array}{c}-16.5760^{* * *} \\
(6.1800)\end{array}$ & $\begin{array}{c}-11.5052^{*} \\
(6.8333)\end{array}$ \\
\hline 5 & & & $\begin{array}{c}-8.4072 * * \\
(3.7467)\end{array}$ & $\begin{array}{l}-7.0555 \\
(4.8320)\end{array}$ \\
\hline
\end{tabular}


medRxiv preprint doi: https://doi.org/10.1101/2020.06.11.20128074; this version posted June 12, 2020. The copyright holder for this preprint (which was not certified by peer review) is the author/funder, who has granted medRxiv a license to display the preprint in perpetuity.

\section{It is made available under a CC-BY-NC-ND 4.0 International license .}

\begin{tabular}{lcccc}
\hline 6 & & & $-12.7560^{* * *}$ & $-10.0471^{* *}$ \\
In GDP per capita & 0.2485 & -0.0591 & -0.4026 & $(4.5988)$ \\
& $(1.1024)$ & $(1.1325)$ & $(1.1398)$ & -0.8913 \\
In population density & 0.0542 & 0.2200 & 0.1598 & 0.3009 \\
& $(0.8772)$ & $(0.8492)$ & $(0.8366)$ & $(0.9004)$ \\
\% age 65 in population & -0.0689 & 0.0031 & 0.0784 & 0.0468 \\
& $(0.2924)$ & $(0.2811)$ & $(0.2826)$ & $(0.2917)$ \\
Temperature & $-0.4738^{* * *}$ & $-0.4930^{* * *}$ & $-0.4551^{* * *}$ & $-0.3903^{* *}$ \\
& $(0.1651)$ & $(0.1483)$ & $(0.1503)$ & $(0.1643)$ \\
Constant & $27.4590^{* * *}$ & $29.1527^{* *}$ & $27.9928 * *$ & $41.3448^{* * *}$ \\
& $(10.4931)$ & $(10.8533)$ & $(10.5507)$ & $(12.4237)$ \\
\hline Number of countries & 142 & 142 & 142 & 142 \\
$\mathrm{R}^{2}$ & 0.310 & 0.323 & 0.335 & 0.408 \\
Adjusted $\mathrm{R}^{2}$ & 0.245 & 0.277 & 0.284 & 0.293 \\
\hline
\end{tabular}

The dependent variable is the percent increase in total cases over the 14 days since the date of the $100^{\text {th }}$ case. The physical distancing measures are those that are in place on the date of the $100^{\text {th }}$ case; refer to Table 1 for the specific measures. Standard errors are in parenthesis. $* * *, * *$, and $*$ represents statistical significance at the $1 \%$, $5 \%$, and $10 \%$ level respectively. N/A denotes not available. 
medRxiv preprint doi: https://doi.org/10.1101/2020.06.11.20128074; this version posted June 12,2020 . The copyright holder for this preprint (which was not certified by peer review) is the author/funder, who has granted medRxiv a license to display the preprint in perpetuity.

It is made available under a CC-BY-NC-ND 4.0 International license.

Table S5. Predicted time-varying reproduction numbers on date of the $100^{\text {th }}$ case

\begin{tabular}{|c|c|c|c|c|c|c|c|c|}
\hline Country & SI & TR & MG & LD & Predicted $\mathbf{R}_{\mathbf{t}}$ & $\begin{array}{l}\text { Estimated } R_{t} \\
\text { using } \\
\text { reported data }\end{array}$ & Difference & $\begin{array}{c}\text { Total cases as } \\
\text { of May 28, } \\
2020\end{array}$ \\
\hline Madagascar & 95.37 & 7 & 4 & 6 & 1.34 & 0.74 & -0.60 & 612 \\
\hline Japan & 25.00 & 6 & 1 & 0 & 1.87 & 1.27 & -0.59 & 16,651 \\
\hline Myanmar & 86.11 & 6 & 6 & 6 & 1.31 & 0.74 & -0.56 & 206 \\
\hline Finland & 42.59 & 6 & 3 & 1 & 1.93 & 1.41 & -0.52 & 6,692 \\
\hline Brunei & 52.78 & 8 & 4 & 0 & 1.25 & 0.73 & -0.52 & 141 \\
\hline Ethiopia & 73.15 & 4 & 6 & 6 & 1.30 & 0.83 & -0.47 & 731 \\
\hline Egypt & 18.52 & 0 & 0 & 3 & 1.80 & 1.33 & -0.47 & 19,666 \\
\hline Iceland & 16.67 & 4 & 0 & 0 & 1.98 & 1.53 & -0.45 & 1,805 \\
\hline Kuwait & 74.07 & 7 & 5 & 3 & 1.33 & 0.89 & -0.44 & 23,267 \\
\hline Thailand & 33.80 & 3 & 3 & 0 & 1.89 & 1.45 & -0.44 & 3,054 \\
\hline Vietnam & 50.00 & 8 & 3 & 5 & 1.51 & 1.10 & -0.41 & 327 \\
\hline Guam & 67.59 & 5 & 6 & 6 & 1.09 & 0.68 & -0.41 & 171 \\
\hline Greece & 40.74 & 0 & 3 & 3 & 1.82 & 1.41 & -0.40 & 2,903 \\
\hline Sweden & 0.00 & 0 & 0 & 0 & 2.15 & 1.75 & -0.40 & 35,088 \\
\hline Bahrain & 25.00 & 1 & 0 & 0 & 1.47 & 1.10 & -0.37 & 9,633 \\
\hline Eswatini & 82.41 & 8 & 4 & 5 & 1.40 & 1.04 & -0.36 & 272 \\
\hline Slovenia & 28.70 & 5 & 4 & 1 & 1.68 & 1.32 & -0.36 & 1,471 \\
\hline Liberia & 79.63 & 6 & 6 & 6 & 1.33 & 0.97 & -0.36 & 266 \\
\hline Iraq & 77.78 & 5 & 6 & 5 & 1.58 & 1.22 & -0.36 & 5,135 \\
\hline Aruba & 82.41 & 6 & 6 & 6 & 1.09 & 0.74 & -0.35 & 101 \\
\hline Norway & 11.11 & 0 & 0 & 0 & 2.13 & 1.79 & -0.34 & 8,383 \\
\hline Rwanda & 100.00 & 8 & 6 & 6 & 1.25 & 0.92 & -0.33 & 346 \\
\hline Senegal & 66.67 & 7 & 6 & 5 & 1.37 & 1.06 & -0.32 & 3,253 \\
\hline Estonia & 44.44 & 1 & 3 & 5 & 1.76 & 1.44 & -0.32 & 1,840 \\
\hline Jordan & 100.00 & 7 & 5 & 6 & 1.39 & 1.09 & -0.30 & 720 \\
\hline Trinidad and Tobago & 79.63 & 8 & 6 & 6 & 0.96 & 0.67 & -0.29 & 116 \\
\hline Andorra & 31.48 & 0 & 1 & 6 & 1.51 & 1.25 & -0.26 & 763 \\
\hline Kosovo & 92.59 & 7 & 6 & 6 & 1.42 & 1.17 & -0.25 & 1,047 \\
\hline Bermuda & 96.30 & 8 & 6 & 6 & 0.95 & 0.71 & -0.25 & 139 \\
\hline Algeria & 36.11 & 5 & 3 & 0 & 1.86 & 1.62 & -0.24 & 8,857 \\
\hline Tanzania & 46.30 & 8 & 4 & 0 & 1.52 & 1.29 & -0.24 & 509 \\
\hline Taiwan & 27.78 & 8 & 1 & 0 & 1.45 & 1.21 & -0.24 & 441 \\
\hline Bulgaria & 70.37 & 6 & 6 & 6 & 1.49 & 1.26 & -0.23 & 2,460 \\
\hline Russia & 60.65 & 6 & 4 & 5 & 2.01 & 1.82 & -0.19 & 370,680 \\
\hline Venezuela & 82.41 & 7 & 4 & 6 & 1.09 & 0.90 & -0.18 & 1,245 \\
\hline Cuba & 66.67 & 6 & 3 & 5 & 1.61 & 1.43 & -0.18 & 1,974 \\
\hline Uruguay & 54.63 & 5 & 3 & 2 & 1.35 & 1.18 & -0.16 & 803 \\
\hline Mozambique & 50.93 & 4 & 4 & 1 & 1.57 & 1.41 & -0.16 & 227 \\
\hline Slovak Republic & 75.00 & 7 & 4 & 4 & 1.36 & 1.21 & -0.16 & 1,515 \\
\hline Ghana & 52.78 & 8 & 4 & 0 & 1.36 & 1.23 & -0.13 & 7,303 \\
\hline Burkina Faso & 84.26 & 7 & 3 & 6 & 1.36 & 1.23 & -0.13 & 845 \\
\hline Afghanistan & 62.04 & 1 & 3 & 6 & 1.55 & 1.42 & -0.13 & 12,456 \\
\hline \multicolumn{9}{|l|}{ Democratic Republic } \\
\hline of Congo & 77.78 & 8 & 4 & 6 & 1.22 & 1.09 & -0.13 & 2,659 \\
\hline Kyrgyz Republic & 92.13 & 8 & 6 & 6 & 1.46 & 1.33 & -0.13 & 1,594 \\
\hline Mauritius & 82.41 & 7 & 3 & 6 & 1.30 & 1.18 & -0.12 & 334 \\
\hline Azerbaijan & 68.52 & 6 & 6 & 5 & 1.67 & 1.56 & -0.12 & 4,568 \\
\hline Hong Kong & 45.37 & 6 & 3 & 2 & 1.23 & 1.11 & -0.11 & 1,066 \\
\hline Albania & 84.26 & 7 & 4 & 6 & 1.43 & 1.32 & -0.10 & 1,050 \\
\hline San Marino & 83.33 & 7 & 6 & 4 & 1.18 & 1.08 & -0.10 & 667 \\
\hline \multicolumn{9}{|l|}{ Bosnia and } \\
\hline Herzegovina & 89.81 & 5 & 6 & 6 & 1.54 & 1.44 & -0.10 & 2,435 \\
\hline Denmark & 35.19 & 3 & 3 & 1 & 2.01 & 1.92 & -0.10 & 11,480 \\
\hline
\end{tabular}


medRxiv preprint doi: https://doi.org/10.1101/2020.06.11.20128074; this version posted June 12,2020 . The copyright holder for this preprint (which was not certified by peer review) is the author/funder, who has granted medRxiv a license to display the preprint in perpetuity.

It is made available under a CC-BY-NC-ND 4.0 International license .

\begin{tabular}{|c|c|c|c|c|c|c|c|c|}
\hline Tunisia & 87.96 & 5 & 5 & 6 & 1.51 & 1.41 & -0.10 & 1,051 \\
\hline Georgia & 100.00 & 8 & 6 & 6 & 1.35 & 1.26 & -0.09 & 735 \\
\hline Pakistan & 52.78 & 6 & 5 & 0 & 1.85 & 1.76 & -0.09 & 61,227 \\
\hline Niger & 61.11 & 7 & 4 & 5 & 1.45 & 1.36 & -0.09 & 955 \\
\hline Cape Verde & 75.93 & 8 & 3 & 6 & 1.32 & 1.24 & -0.09 & 390 \\
\hline Uzbekistan & 90.74 & 7 & 3 & 6 & 1.60 & 1.52 & -0.09 & 3,333 \\
\hline Lebanon & 52.78 & 8 & 1 & 4 & 1.21 & 1.13 & -0.08 & 1,161 \\
\hline Qatar & 30.56 & 6 & 1 & 0 & 1.44 & 1.38 & -0.07 & 48,947 \\
\hline Guyana & 90.74 & 8 & 6 & 6 & 1.07 & 1.01 & -0.07 & 139 \\
\hline Kazakhstan & 80.09 & 7 & 6 & 5 & 1.62 & 1.56 & -0.06 & 9,576 \\
\hline Indonesia & 43.52 & 6 & 3 & 1 & 1.59 & 1.53 & -0.06 & 23,851 \\
\hline India & 48.15 & 6 & 3 & 1 & 1.65 & 1.60 & -0.05 & 158,333 \\
\hline Argentina & 88.89 & 7 & 5 & 5 & 1.59 & 1.54 & -0.05 & 13,920 \\
\hline Paraguay & 93.52 & 7 & 6 & 6 & 1.18 & 1.13 & -0.05 & 884 \\
\hline Kenya & 83.33 & 8 & 6 & 6 & 1.11 & 1.06 & -0.05 & 1,471 \\
\hline Sri Lanka & 97.22 & 8 & 6 & 6 & 1.03 & 0.99 & -0.04 & 1,469 \\
\hline Philippines & 75.00 & 6 & 3 & 5 & 1.63 & 1.60 & -0.03 & 15,049 \\
\hline Bolivia & 96.30 & 7 & 6 & 6 & 1.27 & 1.24 & -0.03 & 7,768 \\
\hline Canada & 22.22 & 2 & 3 & 0 & 2.02 & 2.02 & 0.00 & 87,508 \\
\hline Costa Rica & 71.30 & 7 & 3 & 6 & 1.29 & 1.30 & 0.01 & 984 \\
\hline Czech Republic & 57.41 & 6 & 3 & 3 & 1.81 & 1.82 & 0.01 & 9,086 \\
\hline United Kingdom & 11.11 & 0 & 0 & 0 & 2.04 & 2.05 & 0.01 & 267,240 \\
\hline Chile & 47.22 & 0 & 3 & 5 & 1.86 & 1.87 & 0.01 & 82,289 \\
\hline Congo & 97.22 & 8 & 4 & 6 & 1.12 & 1.13 & 0.01 & 571 \\
\hline Mexico & 2.78 & 1 & 0 & 0 & 1.62 & 1.63 & 0.02 & 78,023 \\
\hline United Arab Emirates & 45.37 & 6 & 3 & 2 & 1.15 & 1.17 & 0.03 & 31,969 \\
\hline Peru & 94.44 & 7 & 5 & 5 & 1.55 & 1.57 & 0.03 & 135,905 \\
\hline Austria & 19.44 & 5 & 0 & 0 & 2.02 & 2.05 & 0.03 & 16,515 \\
\hline Puerto Rico & 93.52 & 6 & 6 & 6 & 1.15 & 1.18 & 0.03 & 3,397 \\
\hline Poland & 57.41 & 7 & 3 & 3 & 1.76 & 1.81 & 0.04 & 22,473 \\
\hline Cyprus & 92.59 & 7 & 5 & 6 & 1.30 & 1.35 & 0.04 & 939 \\
\hline Honduras & 100.00 & 7 & 6 & 6 & 1.21 & 1.26 & 0.04 & 4,640 \\
\hline El Salvador & 88.89 & 8 & 4 & 6 & 1.07 & 1.12 & 0.05 & 2,109 \\
\hline Mali & 72.22 & 5 & 4 & 6 & 1.27 & 1.32 & 0.06 & 1,116 \\
\hline Somalia & 56.48 & 8 & 4 & 1 & 1.38 & 1.44 & 0.06 & 1,731 \\
\hline Ireland & 48.15 & 0 & 5 & 1 & 1.73 & 1.79 & 0.06 & 24,803 \\
\hline Netherlands & 2.78 & 0 & 0 & 1 & 1.88 & 1.95 & 0.06 & 45,768 \\
\hline Serbia & 81.48 & 8 & 6 & 5 & 1.55 & 1.62 & 0.07 & 11,275 \\
\hline Singapore & 25.00 & 6 & 1 & 0 & 1.38 & 1.45 & 0.07 & 32,876 \\
\hline South Africa & 55.56 & 6 & 3 & 1 & 1.64 & 1.71 & 0.07 & 25,937 \\
\hline Romania & 61.11 & 6 & 4 & 3 & 1.65 & 1.73 & 0.08 & 18,594 \\
\hline Sierra Leone & 80.56 & 8 & 4 & 6 & 1.17 & 1.26 & 0.09 & 782 \\
\hline Guatemala & 93.52 & 6 & 6 & 6 & 1.22 & 1.31 & 0.09 & 4,145 \\
\hline Lithuania & 81.48 & 7 & 6 & 6 & 1.45 & 1.55 & 0.10 & 1,647 \\
\hline Nigeria & 82.87 & 8 & 6 & 6 & 1.02 & 1.13 & 0.10 & 8,733 \\
\hline South Sudan & 92.59 & 8 & 6 & 6 & 1.11 & 1.22 & 0.11 & 806 \\
\hline Malaysia & 22.22 & 6 & 1 & 0 & 1.54 & 1.67 & 0.13 & 7,619 \\
\hline Switzerland & 25.00 & 0 & 4 & 0 & 1.85 & 1.98 & 0.14 & 30,678 \\
\hline Saudi Arabia & 68.52 & 7 & 3 & 5 & 1.51 & 1.66 & 0.14 & 78,541 \\
\hline \multicolumn{9}{|l|}{ Central African } \\
\hline Republic & 68.52 & 8 & 4 & 6 & 1.21 & 1.36 & 0.15 & 702 \\
\hline Hungary & 67.59 & 7 & 4 & 4 & 1.34 & 1.49 & 0.15 & 3,816 \\
\hline Cote d'Ivoire & 80.56 & 7 & 4 & 6 & 1.18 & 1.33 & 0.15 & 2,556 \\
\hline Moldova & 87.04 & 7 & 6 & 6 & 1.44 & 1.60 & 0.16 & 7,537 \\
\hline Morocco & 90.74 & 7 & 4 & 6 & 1.38 & 1.55 & 0.17 & 7,601 \\
\hline Panama & 51.85 & 6 & 3 & 1 & 1.51 & 1.69 & 0.18 & 11,728 \\
\hline Cameroon & 57.41 & 5 & 4 & 4 & 1.25 & 1.43 & 0.19 & 5,436 \\
\hline Uganda & 87.04 & 6 & 4 & 6 & 1.39 & 1.58 & 0.19 & 281 \\
\hline
\end{tabular}


medRxiv preprint doi: https://doi.org/10.1101/2020.06.11.20128074; this version posted June $12,2020$. The copyright holder for this preprint (which was not certified by peer review) is the author/funder, who has granted medRxiv a license to display the preprint in perpetuity.

It is made available under a CC-BY-NC-ND 4.0 International license .

\begin{tabular}{|c|c|c|c|c|c|c|c|c|}
\hline Gabon & 87.04 & 8 & 6 & 6 & 1.03 & 1.22 & 0.19 & 2,319 \\
\hline New Zealand & 75.93 & 8 & 6 & 5 & 1.36 & 1.56 & 0.20 & 1,154 \\
\hline Belgium & 13.89 & 1 & 0 & 0 & 1.76 & 1.97 & 0.21 & 57,592 \\
\hline Guinea & 73.15 & 7 & 4 & 6 & 1.22 & 1.44 & 0.22 & 3,446 \\
\hline Croatia & 66.67 & 8 & 5 & 6 & 1.40 & 1.63 & 0.23 & 2,244 \\
\hline Nepal & 92.59 & 8 & 6 & 6 & 1.30 & 1.54 & 0.24 & 886 \\
\hline Luxembourg & 79.63 & 0 & 6 & 6 & 1.44 & 1.68 & 0.25 & 4,001 \\
\hline Colombia & 50.93 & 3 & 4 & 2 & 1.31 & 1.56 & 0.25 & 24,104 \\
\hline Australia & 19.44 & 6 & 0 & 0 & 1.63 & 1.89 & 0.26 & 7,139 \\
\hline Belarus & 8.33 & 5 & 0 & 0 & 2.06 & 2.32 & 0.26 & 38,956 \\
\hline Palestine & 94.44 & 7 & 6 & 6 & 1.27 & 1.54 & 0.26 & 613 \\
\hline Brazil & 42.13 & 3 & 3 & 1 & 1.77 & 2.06 & 0.29 & 411,821 \\
\hline Ukraine & 88.89 & 7 & 6 & 6 & 1.48 & 1.77 & 0.29 & 21,584 \\
\hline Zambia & 65.28 & 8 & 6 & 5 & 1.44 & 1.74 & 0.30 & 1,057 \\
\hline France & 19.44 & 4 & 3 & 0 & 1.87 & 2.21 & 0.34 & 145,746 \\
\hline Ecuador & 93.52 & 7 & 3 & 5 & 1.59 & 1.94 & 0.34 & 38,103 \\
\hline Chad & 88.89 & 8 & 4 & 6 & 1.09 & 1.45 & 0.36 & 715 \\
\hline Benin & 59.72 & 4 & 6 & 5 & 1.41 & 1.78 & 0.37 & 339 \\
\hline Portugal & 32.41 & 5 & 0 & 3 & 1.77 & 2.14 & 0.37 & 31,292 \\
\hline Jamaica & 78.70 & 4 & 6 & 6 & 1.18 & 1.55 & 0.37 & 569 \\
\hline South Korea & 45.37 & 5 & 3 & 0 & 2.07 & 2.45 & 0.38 & 11,344 \\
\hline Oman & 81.48 & 8 & 6 & 6 & 0.97 & 1.35 & 0.38 & 8,373 \\
\hline Spain & 11.11 & 0 & 0 & 0 & 2.02 & 2.40 & 0.38 & 236,769 \\
\hline Dominican Republic & 81.48 & 7 & 3 & 5 & 1.55 & 1.96 & 0.41 & 15,723 \\
\hline Israel & 52.78 & 8 & 4 & 0 & 1.39 & 1.82 & 0.42 & 16,793 \\
\hline China & 8.33 & 0 & 0 & 0 & 2.32 & 2.75 & 0.43 & 84,106 \\
\hline United States & 11.11 & 5 & 1 & 0 & 1.83 & 2.28 & 0.45 & $1,699,933$ \\
\hline Sudan & 81.48 & 8 & 4 & 6 & 1.09 & 1.57 & 0.48 & 4,146 \\
\hline Djibouti & 94.44 & 7 & 6 & 6 & 1.15 & 1.66 & 0.51 & 2,697 \\
\hline Iran & 18.52 & 0 & 3 & 1 & 1.87 & 2.40 & 0.54 & 141,591 \\
\hline Germany & 25.00 & 1 & 1 & 0 & 1.62 & 2.21 & 0.59 & 179,717 \\
\hline Italy & 69.91 & 6 & 5 & 5 & 1.74 & 2.36 & 0.62 & 231,139 \\
\hline Turkey & 58.33 & 6 & 3 & 3 & 1.78 & 2.59 & 0.81 & 158,762 \\
\hline Bangladesh & 87.04 & 6 & 6 & 6 & 1.25 & 2.20 & 0.96 & 38,292 \\
\hline
\end{tabular}

$\mathrm{SI}$ is the Stringency Index, a composite index of physical distancing measures with a range of 0 to 100 , calculated by the Oxford COVID-19 Government Response Tracker (OxCGRT); a larger value indicates higher stringency. TR refers to restrictions on international travel, MG refers to restrictions on mass gatherings, and LD refers to lockdown (see Table 1 for the specific measures). Predicted $R_{t}$ is the average predicted time-varying reproduction number over the two weeks following the date of the $100^{\text {th }}$ case, using a regression model. Estimated $R_{t}$ is the estimated timevarying reproduction number using reported case data, averaged over the two weeks following the date of the $100^{\text {th }}$ case. 
Figure S1. Percent change in mobility on the date of the $100^{\text {th }}$ case and average reproduction numbers in the following two weeks

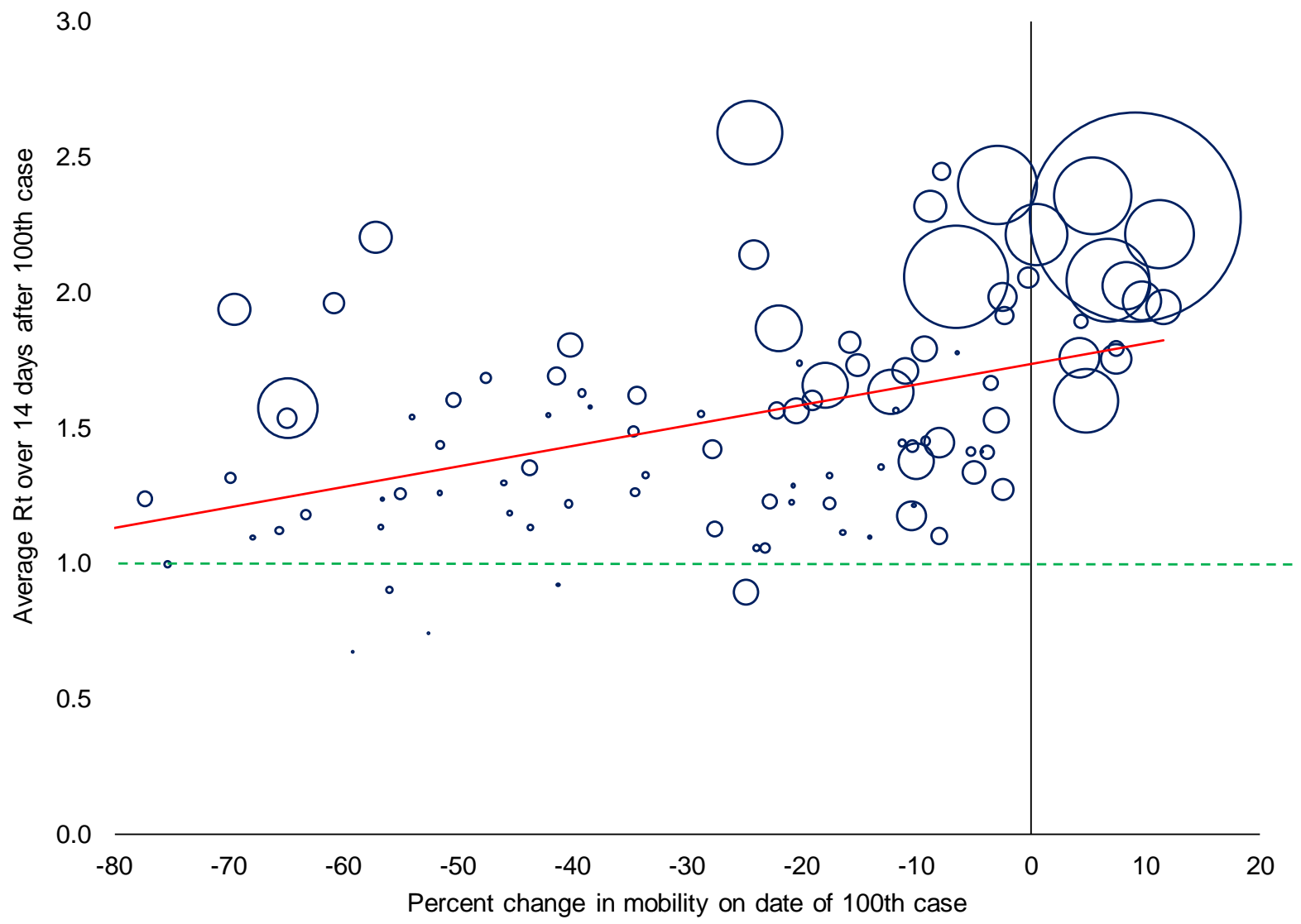

The time-varying reproduction number $R_{t}$ is the expected number of secondary cases generated by a primary case at time $t$. The change in mobility (average of retail and recreation, grocery and pharmacy, parks, transit and workplaces) is relative to the baseline median value of the corresponding day of the week during January 3 to February 6, 2020; data for 103 countries from Google Community Mobility Trends Reports. Each bubble represents a country, and the size of the bubble is proportional to the total number of reported cases as of May 28,2020 . The red solid line is the best linear fit of the relationship between the stringency level on the date of the $100^{\text {th }}$ reported case and the average $R_{t}$ in the following two weeks. The green dashed line is the $R_{t}$ threshold: a value below one indicates that a sustained outbreak is unlikely if the measures remain in place. 